\title{
WestVirginiaUniversity
}

THE RESEARCH REPOSITORY @ WVU

West Virginia Agricultural and Forestry Experiment

Davis College of Agriculture, Natural Resources

Station Bulletins

And Design

$1-1-1936$

\section{A social and economic survey of the Spencer soil- conservation area}

F. D. Cornell

Follow this and additional works at: https://researchrepository.wvu.edu/ wv_agricultural_and_forestry_experiment_station_bulletins

\section{Digital Commons Citation}

Cornell, F. D., "A social and economic survey of the Spencer soil-conservation area" (1936). West Virginia Agricultural and Forestry Experiment Station Bulletins. 269.

https://researchrepository.wvu.edu/wv_agricultural_and_forestry_experiment_station_bulletins/270 @ WVU. It has been accepted for inclusion in West Virginia Agricultural and Forestry Experiment Station Bulletins by an authorized administrator of The Research Repository @ WVU. For more information, please contact ian.harmon@mail.wvu.edu. 
West Virginia University Libraries

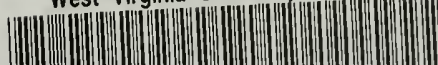

... (.... (n.

308021005212247 



\section{A SOCIAL AND ECONOMIC SURVEY OF THE SPENCER SOIL-CONSERVATION AREA}

By F. D. CORNELL, JR.

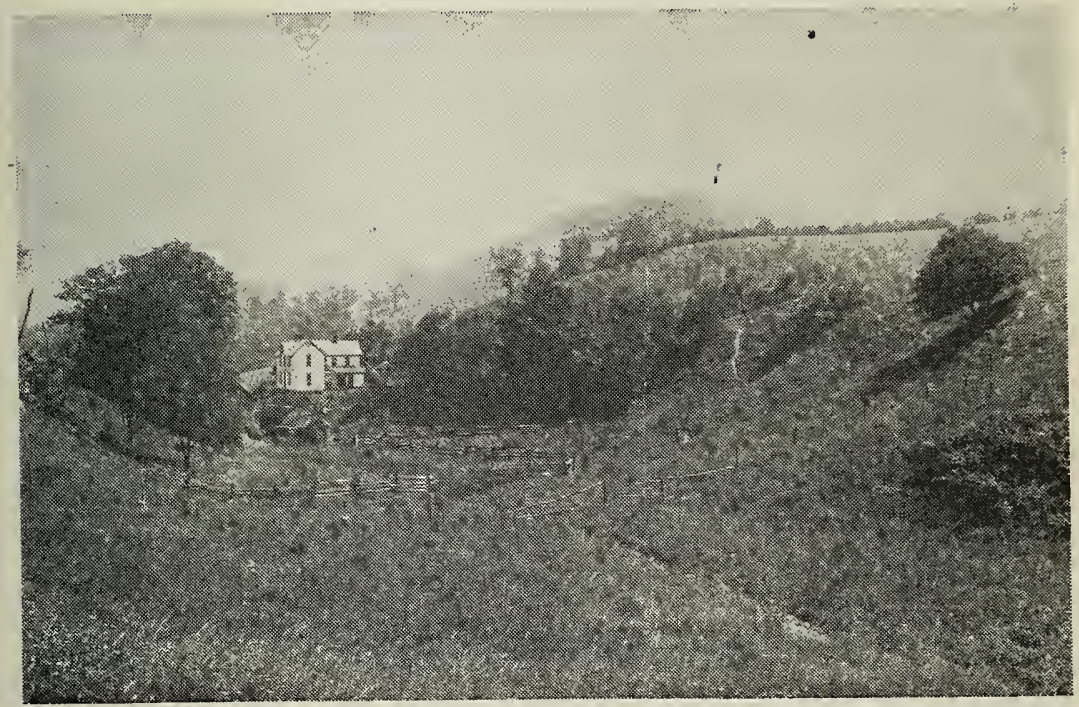

Topography Typical of Much of the Spencer Area

AGRICULTURAL EXPERIMENT STATION COLLEGE OF AGRICULTURE, WEST VIRGINIA UNIVERSITY

F. D. FROMME, Director MORGANTOWN

\section{LISRARY}

WEST VIRUIIVIA UNIVERSITY 


\title{
Agricultural Experiment Station Staff
}

\author{
C. S. BOUCHER, Ph. D., President of the University
}

F. D. FROMME, Ph. D. ................. Dean and Director

GERALD JENNY, M. S., Agricultural Editor....JOHN C. TOHNSTON, Chief Clerk

\section{AGRONOMY AND GENETICS}

R. J. Garber, Ph. D.

Agronomist and Geneticist

W. H. Pierre, Ph. D. Associate Agronomist

T. C. Mellvaine, Ph. D.*† Associate Agronomist

G. G. Pohlman, Ph. D. Assistant Agronomist

C. R. Burnham, Ph. D. Assistant Geneticist

J. A. Rigney, M. S. Assistant in Agronomy

\section{ANIMAL HUSBANDRY}

E. A. Livesay, D. Sc. Animal Husbandman

C. V. Wilson, M. S. Assistant Animal Husbandman

J. H. Longwell, M. A. Assistant Animal Husbandman

R. H. Tuckwiller, B. S. Agr.* Assistant Animal Husbandman

J. H. Rietz, D. V. M. Associate Veterinarian

E. T. Wightman, M. S. Assistant Poultry Husbandman

T. B. Clark, M. S. Assistant Poultry Husbandman

\section{CHEMISTRY}

R. B. Dustman, Ph. D. Agricultural Chemist

C. E. Weakley, Jr., M. A. Assistant Chemist

A. H. VanLandingham, Ph. D. Assistant Chemist

I. J. Duncan, M. S. Assistant in Agricultural Chemistry

DAIRY HUSBANDRY

H. O. Henderson, Ph. D. Dairy Husbandman

L. M. Thurston, Ph. D. Associate Dairy Husbandman

G. A. Bowling, M. S. Assistant Dairy Husbandman

R. A. Ackerman, M. S. Assistant Dairy Husbandman

\section{ENTOMOLOGY}

L. M. Peairs, Ph. D. Entomologist

TV. E. Rumsey, B. S. Agr. Assistant Entomologist

\section{FARM ECONOMICS}

IV. W. Armentrout, Ph. D. Farm Economist

F. D. Cornell, Jr., M. S. Assistant Farm Econonist

C. H. Bruce, B. S. Assistant in Farm Economics

IV. P. Gainer. B. S. Agr. Assistant in Farm Economics

L. F. Herrmann, M. S. Assistant in Farm Economics

\section{HOME ECONOMICS}

Rachel H. Colwell, M. A. Home Economist

Hazel C. Cameron, M. A. Research Specialist in Nutrition

\section{HORTICULTURE}

H. E. Knowlton, Ph. D. Horticulturist

K. C. Westover, M. S. Assistant Horticulturist

L. P. Batjer, Ph. D. Assistant Horticulturist

E. N. McCubbin, M. A. Assistant in Horticulture

A. P. Dye, M. S. Agr. Assistant in Horticulture

IV. H. Childs, M. S. Assistant in Horticulture

\section{PLANT PATHOLOGY}

C. R. Orton, Ph. D. Plant Pathologist

L. H. Leonian. Ph. D. Mycologist

Anthony Berg, M. S. Associate Plant Pathologist

F. J. Schneiderhan, Ph. D.†† Associate Plant Pathologist

* In cooperation with the U. S. Department of Agriculture, Washington, D. C. †In charge of the Lakin Experiment Farm, Lakin, W. Va.

$\ddagger$ In charge of the Reymann Memorial Farms, Wardensville, W. Va.

+ In charge of the University Experiment Farm, Kearneysille, W. Va. 


\section{CONTENTS}

Purpose of the Study _... 5

Methods Used --_-_-_-_-_-

The Spencer Area _......... 6

Topography _...- 7

Soils _-

Climate -._.

Natural Resources _._._._- 8

Population -

Districts Defined _-_-_-_- 9

Social Aspects of the Area

Farm Ownership and Tenure _._._._._._. 9

Ages of Farm Operators _... 10

Location as Affecting Social and Economic Life _-_-________._. 11

Roads - 11

Markets _-_-_._- 13

Schools and Churches _._._. 13

Farm and Home Conveniences _-_._-_._- 14

Farm Homes -

Education - -

Size of Family _... 16

Number of people now living on the farms _..._._. 20

Location and Occupations of Children of Farm Operators -.-.--_-_-_ 20

Origin and Movement of Farmers _-_._- 21

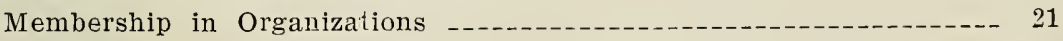

Economic Aspects of the Area

Farm Organization _._-_._- 23

Capital Investment _._-_._- 23

Size of Farms -

Land Utilization -_-_-_._- 26

Utilization of Crop Land and Yields per Acre _-_.........-- 26

Pasture, Woods, and Other Land _-_-_._-_._- 27

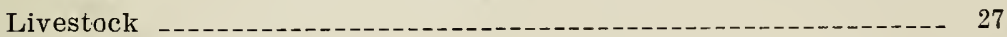

Sources of Farm Receipts _-

Income from Relief Agencies _-_._- 29

Labor Income -

Mortgage Indebtedness _.............. 30

An Analytical Study of 100 High-Income Farms and 100 Low-Income

Farms

Sources of Receipts _._- 32

Crop Yields --_-_-_-_- 33

Soils _-

Erosion -

Summary _- 
In setting forth the factual data regarding conditions in the Spencer area, effort has been made to present a picture of the general situation, rather than a detailed report and analysis of the farm-management situation and all contributing factors. Such analysis is reserved for the final report to be issued upon completion of the project, when comparisons can be made and criteria established for measuring the progress made or the changes which have taken place during the five-year period 


\title{
A Social and Economic Survey of the Spencer Soil-Conservation Area
}

\author{
by F. D. CORNELL, Jr.
}

$T$ HE PROBLEM OF SOIL EROSION has been recognized for years as one seriously affecting agricultural and national welfare. It is only recently, however, that intensive and concerted effort has been made to arrive at practical methods of control. Until 1933, emphasis was on the investigational and educational phases of the problem. However, with the creation of the Soil Erosion Service as an emergency agency of the United States Department of the Interior in September, 1933, the government embarked on a very comprehensive program of erosion control. Demonstration areas were set up in representative locations throughout the country, and under the direction of trained personnel, assisted by the Civilian Conservation Corps, the work has progressed rapidly.

In April 1935 the Soil Erosion Service was transferred to the United States Department of Agriculture and was renamed the "Soil Conservation Service". Not only did Congress authorize such transfer, but the Service at the same time was given status as a permanent governmental agency. This action made possible a long-time program of soil conservation, which is essential if the country is to maintain prosperity on its agricultural lands.

\section{PURPOSE OF THE STUDY}

When the Spencer region was approved as a soil conservation demonstration area, it was felt that a study of the social and economic conditions of the people would have considerable value in carrying on the work and in forming a basis by which improvements brought about in the area as a result of the program undertaken might be measured adequately.

Consequently a cooperative project was approved between the United States Department of the Interior and the West Virginia Agricultural Experiment Station with these objectives in view. The plan was to make a study in the area before any effects of the demonstration program had been realized. Such study was then to be repeated after five years. With the earlier study as a basis for com-

\section{ACKNOWLEDGMNT}

Acknowledgment is made here of the splendid cooperation of the farmers in the Spencer area in furnishing the data for this study. The assistance given by administrative officials and staff of the Spencer Soil Conservation Project is also gratefully acknowledged. The I'nited States Department of the Interior, through the Soil Erosion Service, provided office space for field workers and assisted in obtaining the data in the field and in summarizing the records. 
parison it was felt that improvements brought about as a result of the progran undertaken conld be measured effectively.

The facts and figures set forth in the following report are a result of the study made shortly after the project had been established, shoiving conditions in the area prior to the inauguration of the soil-conservation program.

\section{METHODS USED IN MAKING THE STUDY}

The field work on this project was begun in August 1934 and was completed about November 1, 1934. The work was under the direction of the representative of the Agricultural Experiment Station. Seven fieldmen were employed and the data were obtained by personal visits to the farms. Effort was made to obtain a record irom each farm, regardless of whether the farmer had expressed a desire to cooperate in the program. In ontlining the field work the plan was to obtain as nearly accurate a cross-section of conditions as possible. It is felt that this was accomplished, since records were obtained from 772 farms distributed throughout the area and representing more than 103,800 of the 152,000 acres included in the project.

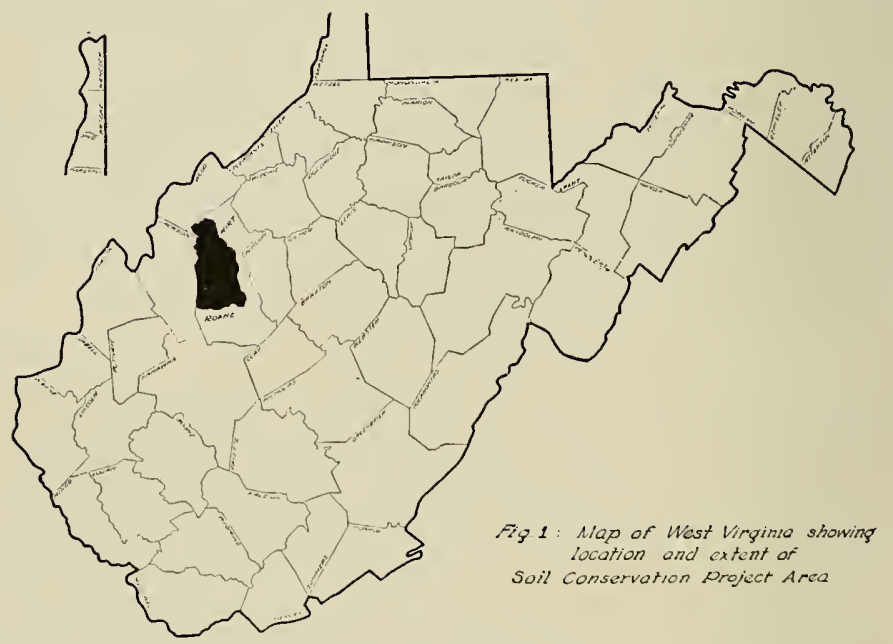

After the records were obtained they were carefully checked and copied in the office, so that upon completion of the field work, a complete set of records was made available to the soil conservation service. All summaries and tabulations were made by the Agricultural Experiment Station.

\section{THE SPENCER AREA}

The Spencer demonstration area was approved late in 1933. The personnel was selected and the work was definitely under way in the spring of 1934. 
The area comprises parts of Wirt and Roane counties and includes within its boundaries some 152,000 acres. This region was chosen because it presented serious crosion problems, because it constituted the watersheds of three creeks - Tucker, Spring, and Reedy - and because the people were willing to cooperate in the project.

Roane and Wirt counties comprised a total of 717.1 square miles, of which 330.4 square miles are included in the demonstration area. This region lies between the parallels of $38^{\circ} 30^{\prime}$ and $39^{\circ} 15^{\prime}$ north latitude and the meridians $80^{\circ} 45^{\prime}$ and $81^{\circ} 45^{\prime}$ west longitude from Greenwich and is about 20 to 30 miles due west of the gengraphical center of the State. (See Fig. 1.)

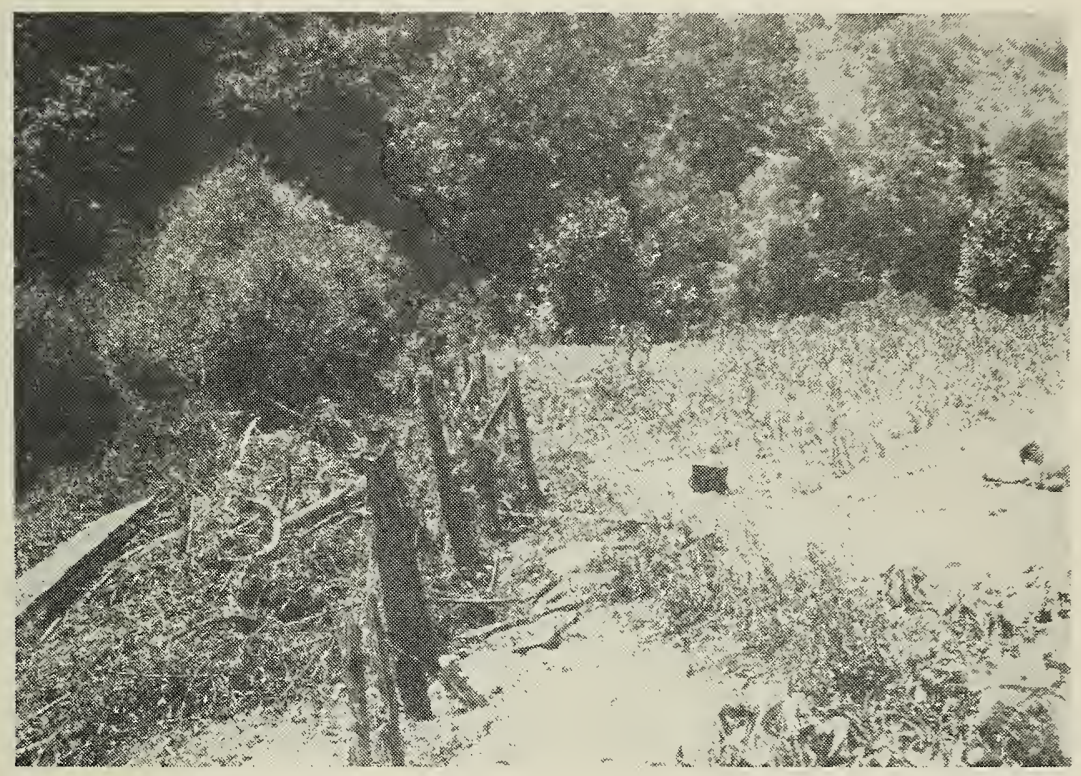

Flood damage on narrow bottom land as a result of stream overflow caused by heavy summer rains. Note the trash and footbridge at the left, and corn buried under 6 to $S$ inches of silt at the right

Topography The Spencer area lies within the Appalachian Plateau and the surface is characteristically rough and broken. with narrow ridges and $v$-shaped valleys. In only a few places do the ridges broaden out into plateau, and the bottom lands along the streams are narrow, in places entirely absent. Along the larger streams the bottom lands attain a width of from one-half mile to a mile. Much of this is composed of terrace or second-bottom areas. The general elevation of the hilltops is about 900 to 1100 feet and the difference between hills and valleys ranges from 100 to 400 feet. The demonstration area is drained by the Litile Kanawha river and its tributaries. 
Soils According to the original soil survey report there are ten principal soil types in the area: namely, Meigs clay loam, Rough Stony land, Upshur clay, Dekalb silt loan, Dekalb sandy loan, Brooke clay loam, Huntington silt loan, Tyler silt loam, Tyler sandy loan, and Moshannon silt loan. The former six are upland soils and the last four are bottom land and terrace soils.

The upland soils are residual, being formed from weathering of rocks of the Carboniferous era of geologic time. The bottom-land soils are a result of deposition by streams along their flood plains. The Meigs clay loan is by far the most common type in the area. The Tyler series are found chiefly on the second-bottom areas, while the Huntington silt loam is the soil commonly found in the bottom land. The Moshannon silt loam has about the same value agriculturally as the Huntington but does not occur as frequently in the area. It may be found particularly in the bottoms along Stover Fork of Reedy Creek. Some of these soils are more susceptible to erosion than others. On the Meigs clay loam erosion is particularly active.

Climate Climatic conditions in the area are particularly favorable to general farming. The mean year-round temperature is about 52 degrees and the average annual rainfall is approximately 40 inches. Rainfall usually is well distributed throughout the year, the months of heaviest rainfall coming during the growing season. Cattle are pastured eight months of the year and need not be tightly housed in the winter. The snowfalls are light and usually melt rapidly.

Natural In Roane and Wirt counties are some of the oldest oil Resources wells in the state. The first oil well drilled in West Virginia was at Burning Springs, Wirt county, about 1860. The development of the oil field in this area enhanced land values, provided incomes to land owners, and detracted from the interest in and attention paid to agriculture. These counties still produce considerable quantities of oil. Although there is coal in the area it has never been developed commercially.

Population 'The population of lioane and Wirt counties increased rapidly from 1860 to 1900 . In 1930, however, the population in both counties was lower than the 1900 figure. Table 1 shows the changes in total population in these counties over a 70 year period. The depletion of the timber in the area and the diminishing production of oil undoubtedly has affected the population. Conversely, the development of these resources between 1850 and 1900 attracted large numbers of people and was a factor in the rapid increase in total population during this period.

Spencer is the largest population center in the area, and agriculture is now the chief occupation of the majority of the people living within the two counties.

Accompanying the decrease in population from 1900 to 1930 there was a decrease in the number of farms. Roane county had 468 fewer 
farms in 1930 than in 1900 and farms in Wirt county had decreased by 652 in the same period. However, the census of 1935 showed a gain of 448 farms in Roane county and 164 in Wirt crunty over the 1930 figures. Thus in 1935 there were still 20 fewer farms in Roane county and 488 fewer in Wirt county than in 1900.

TABLE 1-Changes in population in Roane and Tirt counties from 1860 to 1930

\begin{tabular}{l|r|r}
\hline & \multicolumn{2}{|c}{ COUN'T } \\
\cline { 2 - 3 } YEAR & Roane & Wirt \\
\hline 1860 & 5381 & 3751 \\
1870 & 7232 & 4804 \\
1880 & 12184 & 7104 \\
1890 & 15303 & 9411 \\
1900 & 19852 & 10284 \\
1910 & 21543 & 9047 \\
1920 & 20129 & 7536 \\
1930 & 19478 & 6358 \\
\hline
\end{tabular}

\section{DISTRICTS DEFINED}

For convenience in obtaining the field records, in summarizing the data, and in studying conditions in the various parts of the territory, the project area was divided arbitrarily into eight districts as follows :

District 1 - Tucker creek watershed

District 2-Right Fork of Reedy creek watershed

District 3-Main Reedy creek watershed north of Reedy

District 4-Middle Fork and Seaman Fork of Reedy creek watershed

District 5- Left Fork of Reedy creek watershed

District 6-Spring Creek watershed north of Toms Run

District 7 - Spring Creek watershed north from Spencer to Toms Run

District 8 - Spring Creek watershed south of Spencer

Figure 2 shows the project area, the boundaries of the several districts, the streams and roads in the area, the location of all farm homes, and the location of farms from which records were obtained (indicated by numbers). (See pages 18 and 19.)

In the following discussions and tables the districts referred to by number are those as defined above. These districts do not coincide with and are not to be confused with magisterial districts in the area.

\section{SOCIAL ASPECTS OF THE AREA \\ FARM OWNERSHIP AND TENURE}

One especially striking thing in this area was the low percentage of tenant farmers. By far the greater part of the farmers owned their farms. Many were operating farms which had been inherited and 
which had been "in the family" for long periods. In other cases the prevailing tendency seems to have been to purchase at about the time of marriage or shortly thereafter. The intermediate step to farm ownership (hired hand, tenant, owner) seemed to have been eliminated in a large number of cases.

The majority of the farm population were natives of the region and had always lived in the counties in which they now reside. There seemed to have been little tendency to move from farm to farm after once becoming established, as will be shown later.

Seven hundred twenty-seven or 94.17 percent of the 772 farms from which records were obtained were operated by owners. In other words, the percentage of tenancy in this group of farms was only 5.83 .

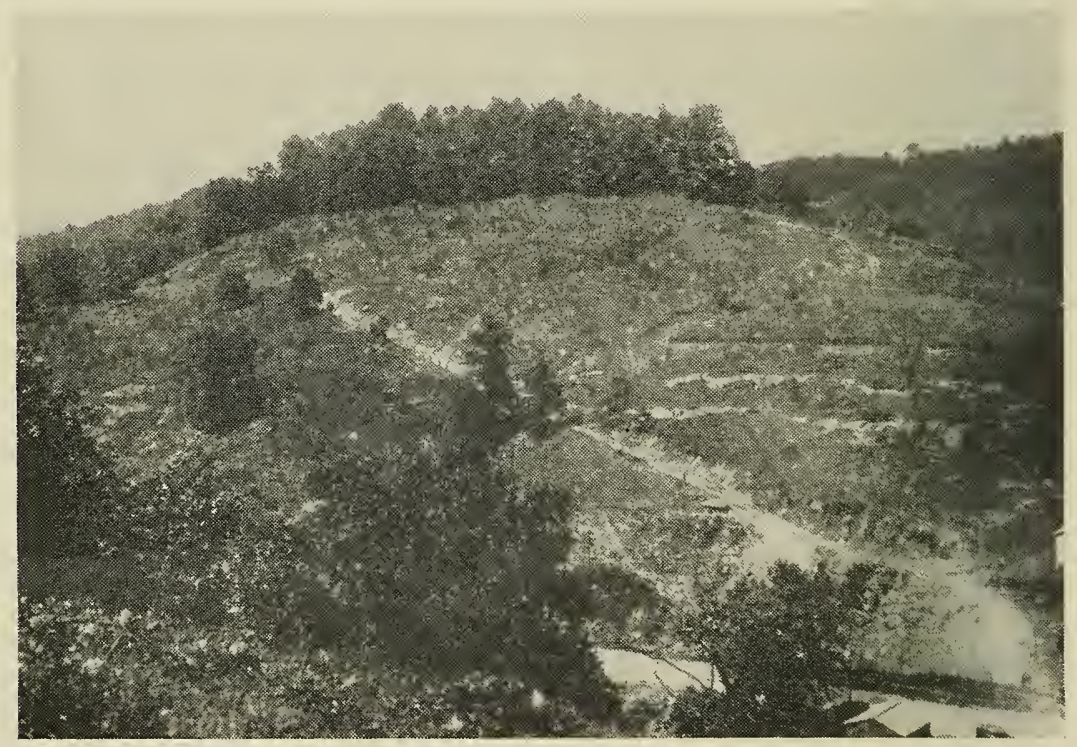

A pasture in the Spencer area showing the effects of erosion

\section{AGES OF FARM OPERATORS}

The younger members of the present generation seem to have been attracted away from the farms in this region. More than 57 percent of the 754 farm operators whose ages were obtained had passed their fiftieth birthday and 31 percent were more than 60 years old. Only 39 of the 754 operators were 30 years of age and less. The average age of all farm operators was 53.4 years.

Because of the advanced age of some of the farmers ( 80 were more than 70 years old), intensive farming operations were not being attempted by them, except where there were children at home who assumed this responsibility. The fact that owners once established 
TABLE 2-Distribution of ages of furm operalors in the slud!y

\begin{tabular}{|c|c|c|c|c|c|c|c|c|c|}
\hline \multirow{2}{*}{ ARE GROUP } & \multicolumn{8}{|c|}{ DISTRICT NIMBER } & \multirow{2}{*}{$\begin{array}{l}\text { Total } \\
\text { all } \\
\text { districts }\end{array}$} \\
\hline & 1 & 2 & $: 3$ & 4 & 5 & 6 & 7 & 8 & \\
\hline $\begin{array}{l}30 \text { yeals or less } \\
31-35 \\
36-40 \\
41-45 \\
46-50 \\
51-55 \\
56-60 \\
61-65 \\
66-70 \\
71-75 \\
75 \text { and over } \\
\text { Total }\end{array}$ & $\begin{array}{r}5 \\
6 \\
13 \\
10 \\
12 \\
17 \\
14 \\
12 \\
9 \\
6 \\
4 \\
108\end{array}$ & $\begin{array}{r}12 \\
9 \\
8 \\
17 \\
12 \\
16 \\
16 \\
21 \\
8 \\
9 \\
6 \\
134\end{array}$ & $\begin{array}{r}5 \\
6 \\
5 \\
12 \\
12 \\
12 \\
12 \\
11 \\
5 \\
5 \\
6 \\
99\end{array}$ & $\begin{array}{r}4 \\
8 \\
13 \\
7 \\
12 \\
14 \\
12 \\
15 \\
7 \\
11 \\
205\end{array}$ & $\begin{array}{r}: 3 \\
9 \\
1: 3 \\
10 \\
10 \\
6 \\
12 \\
12 \\
8 \\
5 \\
5 \\
93\end{array}$ & $\begin{array}{r}4 \\
: 1 \\
7 \\
6 \\
9 \\
7 \\
9 \\
9 \\
11 \\
5 \\
3 \\
73\end{array}$ & $\begin{array}{r}3 \\
2 \\
9 \\
6 \\
8 \\
9 \\
11 \\
7 \\
4 \\
3 \\
3 \\
65\end{array}$ & $\begin{array}{r}: 3 \\
2 \\
5 \\
6 \\
9 \\
11 \\
11 \\
13 \\
10 \\
3 \\
4 \\
77\end{array}$ & $\begin{array}{r}39 \\
45 \\
77 \\
74 \\
84 \\
92 \\
97 \\
100 \\
66 \\
47 \\
33 \\
754\end{array}$ \\
\hline
\end{tabular}

have been prone to cling to and operate their farms, and that most of the desirable farming land now is held by owner-operators, may account to some extent for the low percentage of young men now owning or operating farms in the area. Table 2 shows the distribution of farm operators in various age groups by districts and for the area as a whole.

The average age of the farm operators at the time of marriage was 25.04 years.

\section{LOCATION AS AFFECTING SOCIAL AND ECONOMIC LIFE}

Roads Two main highways pass through parts of the area. With the exception of the farms located on these main arteries, all the farms are on dirt roads. Generally speaking, the dirt roads parallel fairly closely the meanders of the streams draining the territory. The area is covered by a network* of dirt roads, most of which are narrow and poorly maintained. Some parts of the area are almost inaccessible at certain periods of the year. The kind and condition of the roads in many parts of the area make travel slow and difficult and hamper social and trading activities.

TABLE 3-Kind of rouds on which farms were located in the spencer area (759 farms)*

\begin{tabular}{c|c|c|c}
\hline \multirow{2}{*}{ DISTRICT } & \multicolumn{2}{|c}{ NTMBER OF FARMS LOCATED ON } \\
\cline { 2 - 4 } & $\begin{array}{c}\text { Paved } \\
\text { road }\end{array}$ & $\begin{array}{c}\text { Gravel } \\
\text { road }\end{array}$ & $\begin{array}{c}\text { Dirt } \\
\text { road }\end{array}$ \\
\hline 1 & 9 & 0 & 100 \\
2 & 6 & 2 & 126 \\
3 & 24 & 0 & 83 \\
4 & 2 & 6 & $\mathbf{1 0 0}$ \\
5 & 23 & 13 & $\mathbf{5 4}$ \\
7 & 0 & 1 & $\mathbf{7 0}$ \\
8 & 6 & 4 & 55 \\
Total & 11 & 31 & 59 \\
\hline
\end{tabular}

*13 records are incomplete.

*Figure 2 shows the existing road system in the spencer area. 


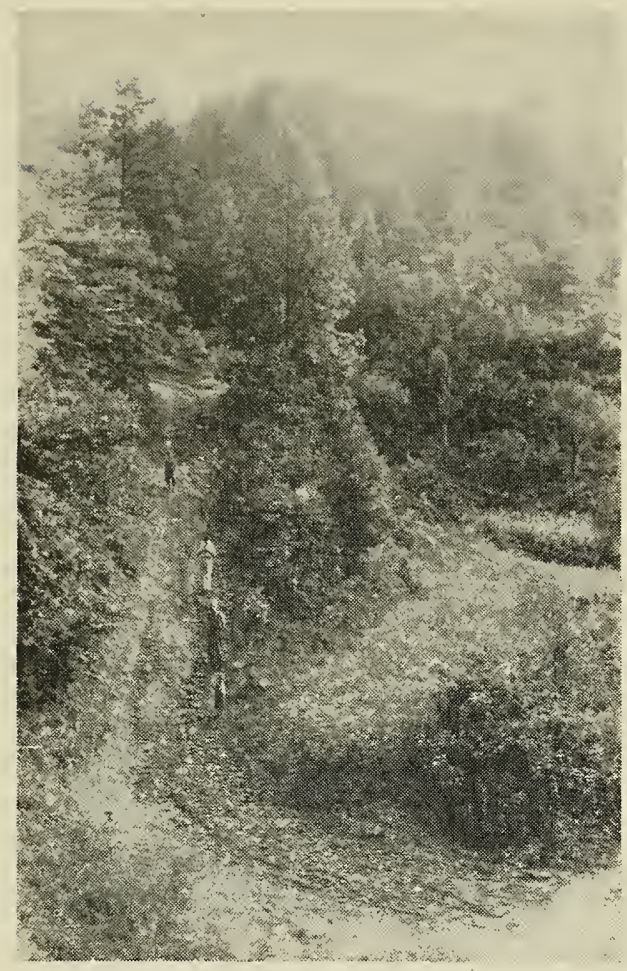

An example of the poorest type of road in the area

the farms to the nearest paved road. tion by districts and for the area as a whole is shown in Table 4 . which shows that 286 farms were more than three miles from any paved road. One hundred sixteen of these farmers had more than 5

TABLE 4-Distribution of farms according to number of miles to nearest paved road

\begin{tabular}{|c|c|c|c|c|c|c|c|c|c|}
\hline \multirow{2}{*}{ MILES } & \multicolumn{8}{|c|}{ DISTRICTS } & \multirow{2}{*}{ Total } \\
\hline & 1 & 2 & 3 & 4 & 5 & 6 & 7 & s & \\
\hline Less than 1 & 14 & 12 & 27 & 20 & 12 & 2 & 19 & 27 & 133 \\
\hline 1 to 2 & 17 & 2 & 22 & 16 & 12 & 3 & 12 & 17 & 101 \\
\hline 2 to 3 & 30 & 13 & 5 & 21 & 4 & 5 & 3 & 11 & 92 \\
\hline 3 to 4 & 18 & 23 & 13 & 18 & 5 & 22 & 2 & 8 & 109 \\
\hline 4 to 5 & 11 & 13 & 3 & 12 & 3 & 12 & 6 & 1 & 61 \\
\hline 5 to 6 & 5 & 13 & 2 & 7 & 3 & 14 & 2 & .. & 46 \\
\hline 6 to 7 & 3 & 14 & $\ldots$ & $\ldots$ & & 1 & 9 & . & 27 \\
\hline 7 to 8 & 2 & 8 & $\cdots$ & $\cdots$ & 2 & 3 & 2 & $\cdots$ & 17 \\
\hline 8 to 9 & . & 7 & $\ldots$ & $\ldots$ & $\ldots$ & 1 & $\ldots$ & . & 8 \\
\hline 9 to 10 & . & 7 & $\ldots$ & $\cdots$ & . & $\ldots$ & $\ldots$ & . & 7 \\
\hline More than 10 & .. & 9 & $\ldots$ & $\ldots$ & 2 & .. & $\ldots$ & .. & 11 \\
\hline On paved road & 9 & 6 & 24 & 2 & $2 \overline{3}$ & $\ldots$ & 6 & 11 & 81 \\
\hline
\end{tabular}

ber of farms located on paved, gravel, and dirt roads in the variots districts and in the area as a whole.

Of the 759 farms on which accurate data could be ol)tained, only 81 were located along paved highways. Thirty-one farms were on gravel roads. The remaining 647 farms were located on dirt roads.

A location on a dirt road is no serious disadvantage if within easy reach of a maintraveled highway. 'The added difficulty and cost of carrying on trading and marketing activities which require travel over several miles of narrow, steep, and rough roads, however, is apparent. A large percentage of the farms in the Spencer area have this situation with which to contend. Data were obtained, in so far as possible, as to the distance from A summary of this informa-

\section{Table 3 shows the num-}

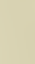

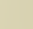


TABLE 5-Distribution of farms according to number of miles to nearest marlet

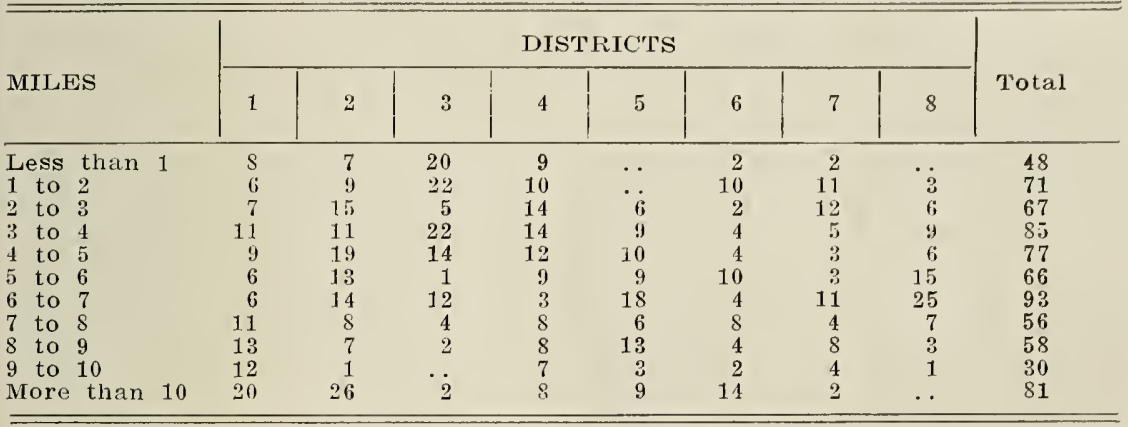

miles of dirt road to travel in order to reach the main highway. The importance of good roads in facilitating marketing and social activities is very generally recognized.

Markets The Spencer area is primarily a livestock producing center, a very large percentage of the livestock and livestock products being shipped out of the territory. The location of farms with reference to market outlets, however, is always an important economic consideration. Data were obtained from 732 farms as to the distance from the farms to the nearest market. Table 5 shows the farms distributed according to the number of miles to market.

An examination of Table 5 reveals that more than half of the farms were further than five miles from any market. As has been indicated, a considerable percentage of this distance was over dirt roads. Eighty-one of the farms were more than ten miles from market. The distances, combined with the condition of many of the roads, make marketing difficult for farmers in many parts of the area.

Schools and There were schools within convenient reach of most of Churches the farm families. Four hundred sixty-six of the farms included in the survey were less than a mile from the nearest school and 669 were nearer than two miles. Table 6 shows the farms distributed according to the distance from the nearest school.

As can be seen from Table 6 none of the farms was more than TABLE 6-Distribution of farms according to number of miles to nearest school

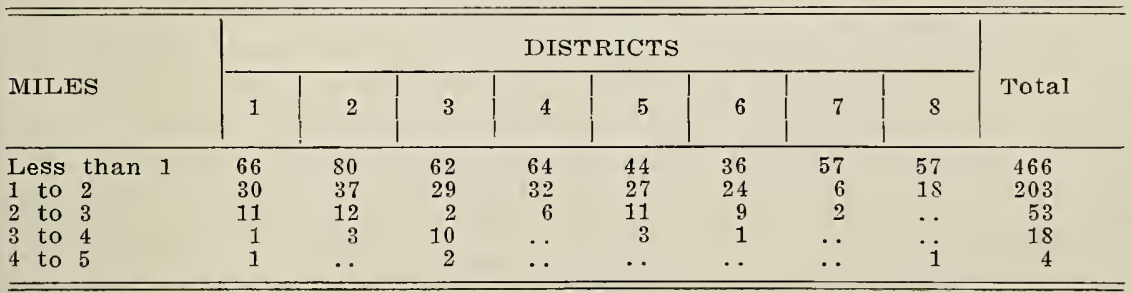


five miles from a school. The children from 22 of the farm families were required to travel from 3 to 5 miles to obtain an education.

The situation as regards the location of farms with reference to a high school, however, was not as favorable. The high schools in the area are located at Spencer and Elizabeth. With the County Unit systen in force and with bus transportation avalable the handicap of distance is mitigated considerably. Table 7 shows the farms distributed according to the distance from the nearest high school. It can be seen from this table that 300 of the farms were more than 10 miles from any high school, and children atteriding high school from 601 of the farms were required to travel more than 5 miles. The extent of the formal education received by the farm families in the conservation area is discussed later.

TABLE 7-Distribution of farms according to number of miles to nearest high school

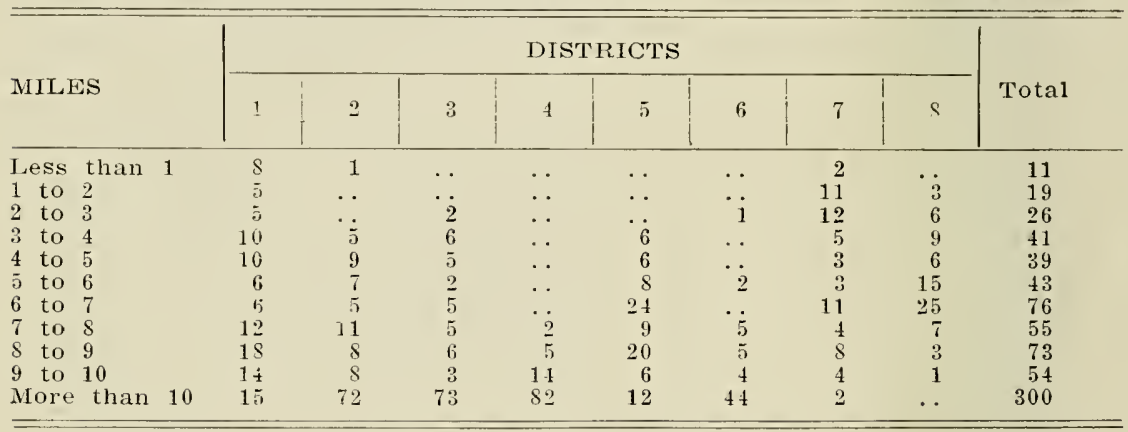

Churches were scattered numerously throughout the territory and in most cases could be reached by the farm families without difficulty. Table 8 shows the farms distributed according to the distance from the nearest church and shows that 439 of the farms were within a mile of a church, and 689 of the families need travel less than two miles to the nearest services. The churches are the religious and social centers of community life as is indicated by participation in church activities (See page 21.).

\section{FARM AND HOME CONVENIENCES}

Some appreciation of the situation on the farms with respect to modern conveniences may be obtained from the summary of information found in Table 9, which shows the number of farms which reported the equipment indicated in each district. Only two furnaces were reported in the entire area. Fifty-seven farm homes had running water with bath equipment. Twenty-seven farms had electric lights and 199 homes were lighted with gas.

The use of tractors, trucks, and stationary engines was limited. However, radios were found in appreciable numbers; 34 percent of the farmers owned automobiles, and there were telephones in 67 percent of the homes. 
Water Supply One of the factors contributing to comfort and convenience in the home and on the farm is rmoning water. On 160 farms such was available within the house. ()n thirty of these farms water was piped to other buildings also. Only 57 of the 160, however, had complete installations with bath equipnent. On the remaining 80 percent of the farms water for houschold uses was carried from ontside. The distances water harl to be carried ranged from 2 to 1800 feet, or an average distance of 44 feet.

TABLE S-Distribution of farms according to number of miles to nearest church

\begin{tabular}{|c|c|c|c|c|c|c|c|c|c|}
\hline \multirow{2}{*}{ MILES } & \multicolumn{8}{|c|}{ DISTRICTS } & \multirow{2}{*}{ Total } \\
\hline & 1 & 2 & 3 & 4 & 5 & 6 & 7 & $\varepsilon$ & \\
\hline Less than 1 & 68 & 74 & 65 & 72 & 34 & 25 & 45 & $\div 6$ & $43 !$ \\
\hline 1 to 2 & 35 & 47 & $3 \pi$ & 22 & +2 & 32 & 17 & 20 & 250 \\
\hline 2 to 3 & 4 & 11 & 4 & fi & 13 & 13 & 1 & $\ldots$ & 52 \\
\hline 3 to 4 & . & $\ldots$ & 3 & 2 & 2 & 2 & 2 & $\ldots$ & 9 \\
\hline 4 to 5 & 2 & $\ldots$ & $\ldots$ & $\cdots$ & . & . & . & . & 2 \\
\hline
\end{tabular}

TABLE 9-Number and lind of conveniences on the farms stidicd

\begin{tabular}{|c|c|c|c|c|c|c|c|c|c|c|}
\hline \multirow[b]{2}{*}{ DISTRICT } & \multicolumn{6}{|c|}{ NUMBFR OF FARMS } & \multicolumn{4}{|c|}{ REPORTING } \\
\hline & 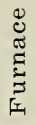 & $\underset{\pi}{\stackrel{\pi}{\pi}}$ & $\stackrel{\circ}{\frac{1}{3}}$ & 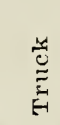 & 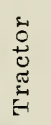 & 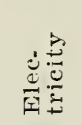 & $\stackrel{\varpi}{\overparen{\sigma}}$ & $\stackrel{0}{\stackrel{0}{Z}}$ & 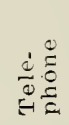 & 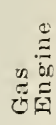 \\
\hline 1 & 0 & 7 & 36 & 4 & 0 & 5 & 7 & 17 & 55 & 22 \\
\hline 2 & 0 & 1 & 25 & 0 & 1 & 0 & 2 & 13 & 108 & 3 \\
\hline 3 & 1 & 4 & 28 & 2 & 1 & 0 & 10 & 14 & 63 & 9 \\
\hline 4 & 1 & 10 & 29 & 3 & 0 & 2 & 31 & 19 & 84 & 14 \\
\hline 5 & 0 & 19 & 59 & 5 & 3 & 15 & 62 & 26 & 71 & 12 \\
\hline 6 & 0 & 1 & 22 & 1 & 0 & 0 & 3 & 5 & 52 & 4 \\
\hline 7 & 0 & 5 & 27 & 3 & 0 & 3 & 50 & 16 & 28 & 9 \\
\hline$\dot{S}$ & 0 & 10 & 38 & 2 & 1 & 2 & 34 & 15 & 57 & 15 \\
\hline Total & 2 & 57 & 264 & 20 & 6 & 27 & 199 & 125 & 518 & 88 \\
\hline
\end{tabular}

Wells were the source of water supply on 552 of the farms. Springs supplied water on 82 farms and cisterns on 64 . On the remaining farms two sources were used as well and spring, well and cistern, or cistern and spring.

In many cases the protection afforded at the source of supply against contamination was very inadequate, as is indicated by the fact that the sources of supply on 139 farms were not protected against seepage and surface run off. This situation constitutes a serious menace to the health of a large group of the farm population.

\section{FARM HOMES}

Information was obtained as to the type of construction and the condition of the homes on the farms from which records were obtained. The condition of the houses is a fair indication of the general standard of living in rural sections and reflects to some degree the financial success of the farming enterprise. 
There were $30 \log$ houses, $18 \log$ and frame. 3 boxed construction, 687 frame construction, two each of brick and roncrete, and 1 of stone. Of these, 365 were rated as being in only fair condition and 160 were poor. Two hundred of the houses never had been painted.

\section{EDUCATION}

The extent of the formal education of the adult population of an area has a bearing on the social and econonnic conditions there existing. Although it was impossible to obtain accurate information in every case as to years of school attendance of both farm operators and their wives, such data were obtained for a large percentage of

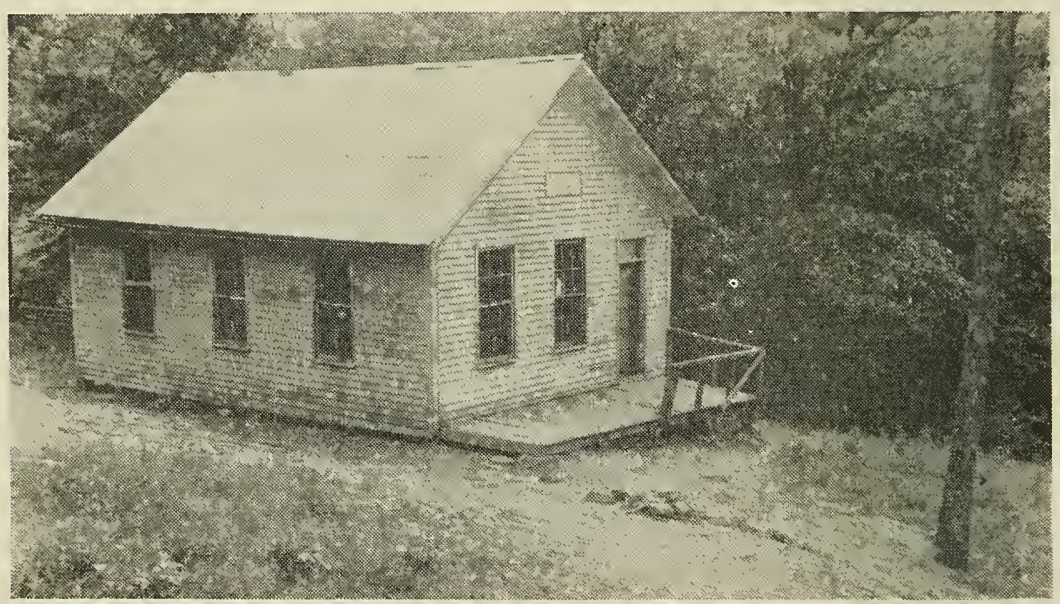

A rural school in the Spencer area

these groups and are summarized in Table 10, which shows the years of school attendance of 712 operators and 605 wives. Of this number, 441 men and 455 women had attended school eight years or less. One huncled fifty-one men and ninety-seven women had obtained less than six years of formal education. In other words, 61.9 percent of the men and 75.2 percent of the women had not more than a common-school education, and 7.7 percent of the men and 3.5 percent of the women had continued their education beyond the equivalent of the high school.

\section{SIZE OF FAMILY}

There had been 3175 children born in the families included in the study. Of these, 258 had died before the survey. Eighty six of the 258 dies in infancy or before reaching 1 year of age. The number of children per family ranged from 0 to 18 , the arerage number for all families being 4.1. Table 11 shows the distribution of families to 

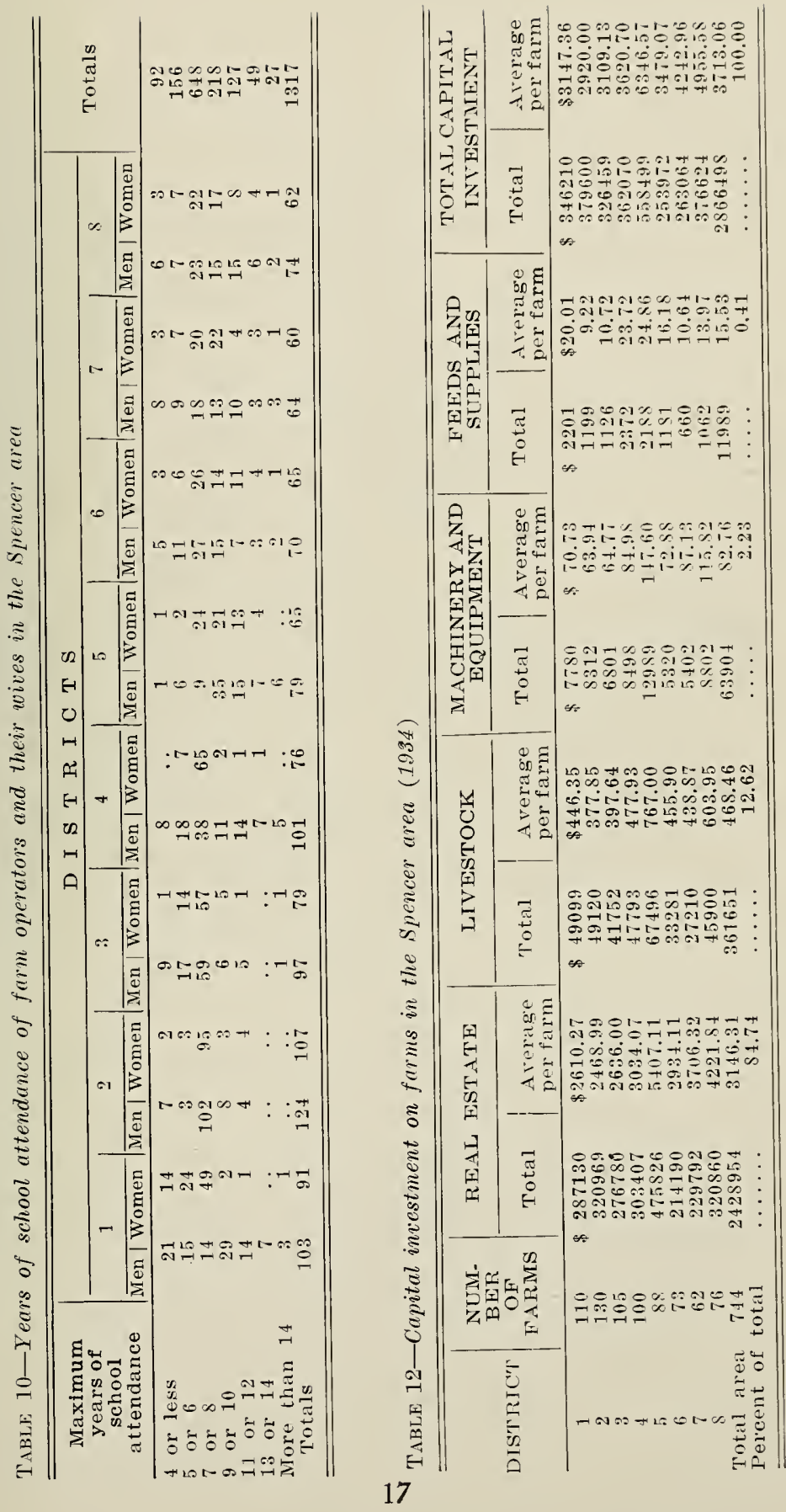


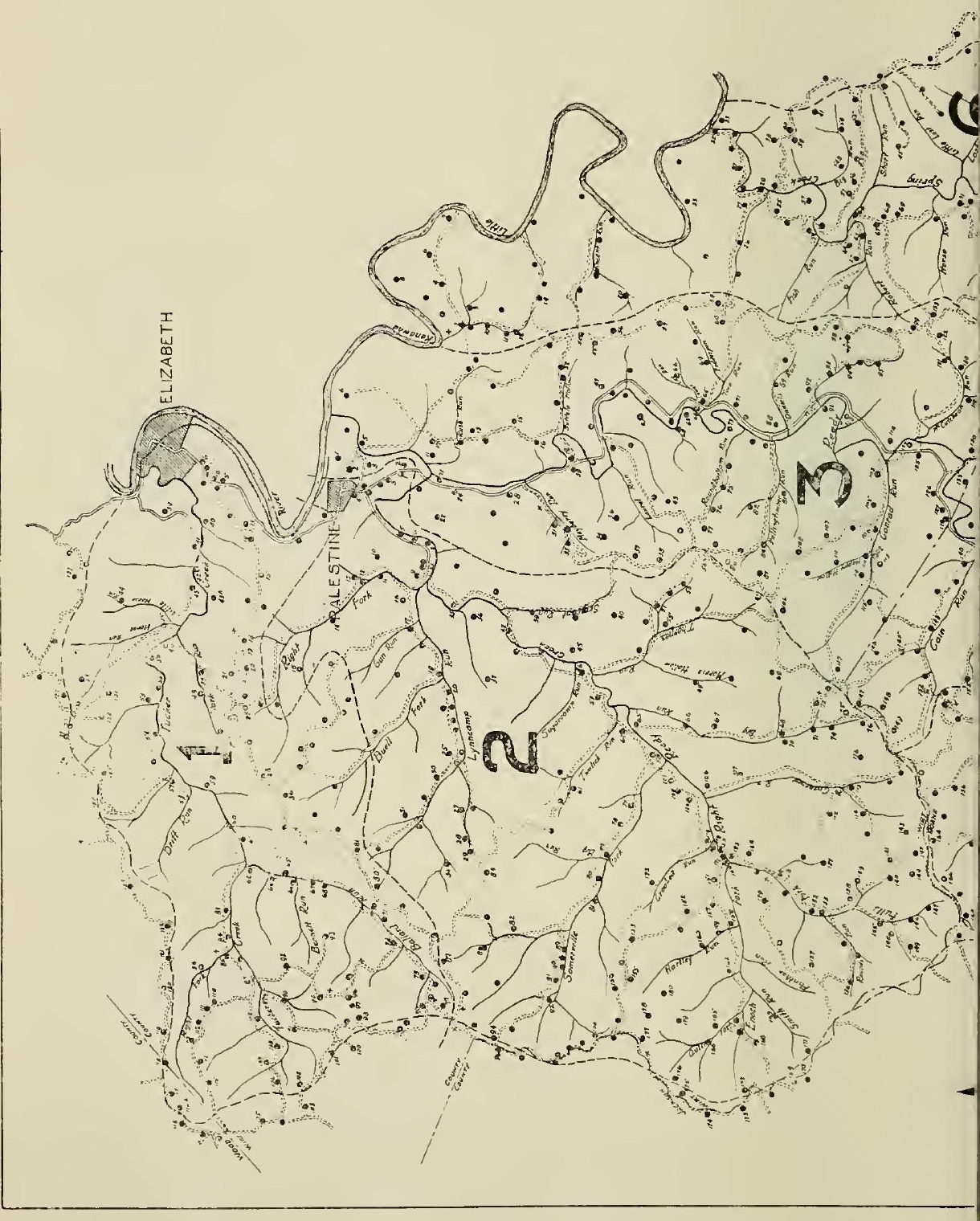

Fig. 2-The Spencer Area: Districts which records 


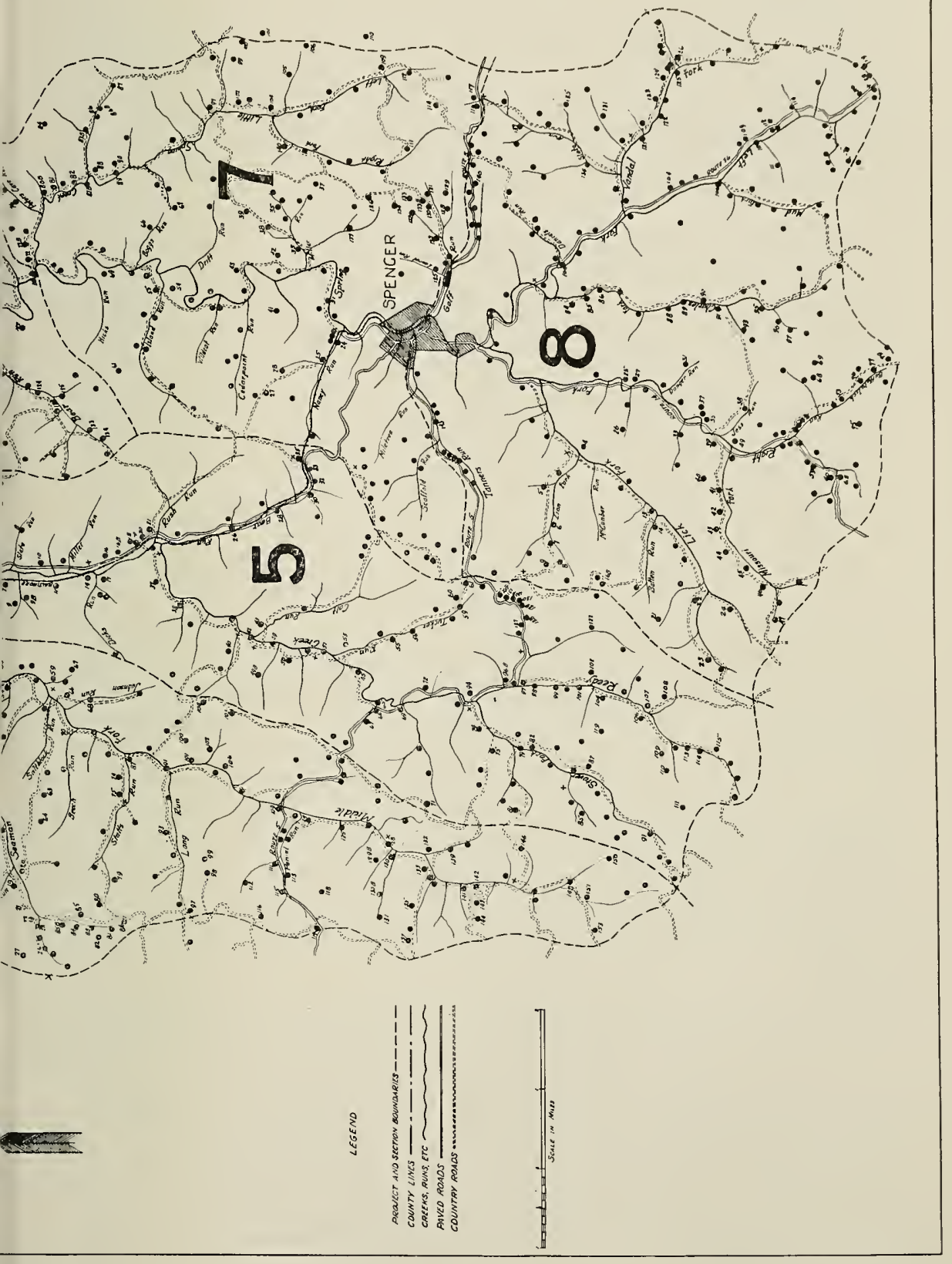

all farm homes, and farms from the study 
which children had been born according to the number of children per family.

The leaths of infants under 1 year of age per 1000 births in West Virginia from 1925 to 1928 inclusive were 80, 82, 72, and 70 respectively: In the group of chiliren here reported, the infan: death rate had been 27 per 1000 births. If only those families having children were considered, the average number of children per family was t.7. With a comparatively high birth rate the low infant mortality anong these farm families is noteworthy.

TABLE 11-Distribution of farm famitics in the spencer arca according to number of children born per family

\begin{tabular}{|c|c|c|c|c|c|c|c|c|c|}
\hline \multirow{2}{*}{$\begin{array}{l}\text { Number of } \\
\text { children born } \\
\text { per family }\end{array}$} & \multicolumn{8}{|c|}{ DISTRICTS } & \multirow[b]{2}{*}{ Totals } \\
\hline & 1 & 2 & 3 & 4 & 5 & 6 & 7 & $s$ & \\
\hline 1 & 12 & 13 & 9 & 4 & 11 & 8 & 7 & 4 & $6 s$ \\
\hline 2 & 18 & 17 & $1: 3$ & 9 & 16 & 6 & 3 & 12 & 94 \\
\hline$\overline{3}$ & 3 & $\because 3$ & 15 & 11 & 17 & $\tau$ & 11 & 10 & 103 \\
\hline 4 & 16 & 16 & 15 & 18 & 8 & 7 & $s$ & 6 & 94 \\
\hline$\vdots$ & 10 & 19 & 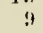 & 7 & 8 & $\tau$ & 5 & 14 & 79 \\
\hline 6 & 14 & 9 & 10 & 10 & 6 & 10 & $s$ & 5 & 72 \\
\hline 7 & 10 & 10 & 5 & $\tau$ & 5 & 9 & 2 & 8 & 56 \\
\hline s & 6 & 5 & 5 & 9 & 2 & 4 & 4 & 7 & 42 \\
\hline 9 & 4 & 3 & $\ddot{3}$ & 7 & $\overline{2}$ & $\because$ & 2 & $\ldots$ & 30 \\
\hline 10 & 1 & 1 & 1 & 5 & . & 4 & 3 & $\because$ & 15 \\
\hline 11 & 1 & 2 & 1 & 2 & $\therefore$ & 1 & 1 & $i$ & 9 \\
\hline 12 & & & 3 & 1 & $\ldots$ & .. & 1 & 2 & 7 \\
\hline Nore than 12 & & 1 & & 3 & & & & 1 & 5 \\
\hline Total & 101 & 119 & 95 & 93 & 75 & 66 & 55 & 70 & 674 \\
\hline
\end{tabular}

Number of People The number of children per family does not inNow Living on Farms dicate the number of people now living on the farms. A large percentage of the children of these farm operators were grown and had left home. Others were living with the families, such as relatives and hired help. The population actually living on the farms at the time of the study was 4313 , or an average of 5.58 persons per farm. These figures include only those in the farm operator's household. In other words, the major portion of the living of 431.3 people in the area was being obtained from the 103,800 acres in the farms covered by the study.

\section{LOCATION AND OCCUPATIONS OF CHILDREN OF FARM OPERATORS}

A study was made of the location and occupations of those children of farm operators who had passed their 21 st birthday or had married. There were 814 sons who could be so classified. Of this number 401 or nearly 50 percent were engaged in farming. Thirty-eight had left Roane and Wirt counties and were on farms elsewhere; $16 t$ were on farms within these coninties and 199 were still on the home farms. There were 283 who had gone into industrial work, 62 within the area, and 221 elsewhere. Sixty-nine were in business; 25 within the area and 44 outside. Sixty-one were in pro- 
fessional or administrative work; 30 within the area and 31 clsewhere. Three hundred thirty-four of the 814 sons had left their home counties and were engaged in occupations under the general classifications indicated.

There were 713 datighters who had married or were past 21 years of age. Of these 173 were wives of farmers in the area and 35 were wives of farmers living outside Roane and Wirt counties. Ninety had married workers in fields other than agriculture but were still living in the area, while 268 had married workers in other than agricultural occupations and had left the area.

Eleven were engaged in business pursuits, 4 in the area and seven outside. Ten were in industry; 1 in the area and 9 elsewhere. Twenty-seven were in professions, 17 in the area and 10 in other locations. Eighty-nine were engaged at housework on the home farms, 5 in other homes in the area, and 5 ontside the counties. Three hundred thirty-four of the 713 daughters were living in areas other than Roane or Wirt counties. The percentage of either sons or daughters who had left the state was very low.

Of those who had left the home farms 281 sons and 290 daughters were still living in the area, and $33+$ sons and 334 daughters were living outside of Roane and Wirt counties. Two hundred eight daughters had married farmers and 202 sons were engaged in farming.

\section{ORIGIN AND MOVEMENT OF FARMERS}

Although farming in a region cannot furnish occupation for all the children produced by the farming population, it is an occupation that is handed down from parents to children perhaps to a greater extent than any other. Thus the agriculture of an area is carried forward by the same type of population with little geographical shifting, and the rural areas have a continuing stable social organization.

These facts were borne out by the data obtained in the Spencer study. Only 20 of the farm operators had been born in villages or towns. All others had been born and reared on farms. Many operators were still living on farms on which they had been born. A large percentage of the farmers had moved from farm to farm during their careers, but practically all such moves had been made within the general surrounding area and not from one region to another. There had been some movement from farm to town and vice versa, but such moves were comparatively few.

\section{MEMBERSHIP IN ORGANIZATIONS}

There were 1592 members of the families included in the survey who were affiliated with church organizations; 387 were nembers of a lodge; 134 belonged to $4-\mathrm{H}$ Clubs; 176 were members of cooperative organizations; 8 participated in Farm Women's club activities; 66 were members of other women's organizations, 19 had joined community organizations, and 11 were members of ParentTeachers associations. 
A business record of the farming cnterprise covering the period from June 1, 1933, to June 1, 19.34, was obtained from each farm included in the survey. In a few exceptional cases these records were incomplete in certain items because of inability to secure accurate information. In the following summaries and tabulations only those records complete in the details under discussion were included.

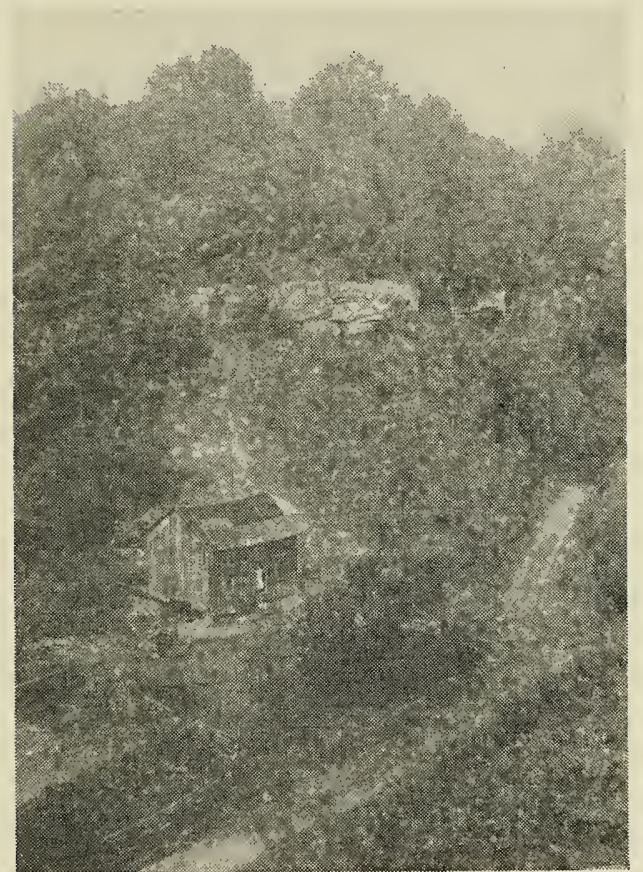

In such parts of the area as this farming can never return more than subsistence

The type of farming in the Spencer area is livestock, with the greater percentage of farm receipts coming from the sale of livestock and livestock products. The important factors in determining the type of farming in this area have been topography, soils, climate, and distance from market.

The quality of the livestock produced in Roane and Wirt counties has been much improved in recent years, and Spencer is the center of livestock buying, selling, and shipping activities for the area. Sales are held at the Spencer yards each Friday throughout the season and large numbers of livestock are handled in the course of the year's trading.

At present sheep are raised in large numbers in the area. Fine-wool sheep, althongh raised at one time in these counties in considerable numbers, have practically disappeared. Most of the sheep now found are of the coarse-wool breeds.

Although fruit may be found in abundance on the farms in Roane and Wirt counties, there is no commercial orcharding activity in the area. Hogs are found in considerable numbers on the farms but they are raised almost entirely for home consumption. There are no large dairy herds in the area, although the enterprise is sufficiently developed to supply local demands for fluid milk.

The originally abundant blue-grass pastures in many parts of the area have become seriously depleted as a result of erosion, unwise pastnring practices, lack of attention, and improper treatment, 
until the carrying capacity of much of the pasture area and the quality of the forage have been reduced. This situation if allowerl to continue unchecked is serious because of its direct relation to the enterprise on which the majority of the farm population depends for a livelihood.

\section{FARM ORGANIZATION}

Capital The total investment in real estate on the farms inInvestment cluded in the study was $\$ 2,428,954$, and the total capital investment represented was $\$ 2,866,498$. The items of capital and the percentage each represents of the total are shown in Table 12. This table shows that the average capital investment per farm was $\$ 3,713.06$, of which $\$ 3,146.31$ or 84.74 percent was in real estate, $\$ 468$ or 12.62 percent in livestock, $\$ 83$ or 2.23 percent in machinery and equipment, and $0.4 \%$ in feeds and supplies.

The investment in machinery and equipment was low in this area. This was due to the fact that much of the machinery had depreciated rapidly in the last few years, since farmers had bonght only what was necessary. Then too, in this area much of the work of planting, harvesting, and cultivating was accomplished by hand methods because of the topography.

Size of The farms studied varied in size from 5 to 1800 acres. The Farms number of extremely large farms was low, as was alsn the number of very small farms. The average size of all farms was 134.5 acres. Table 13 shows the farms distributed according to the total acreage per farm.

Six hundred forty-five or 83.5 percent of the farms were smaller than 200 acres. The average size of farm in Roane county according to the 1935 census was 104.7 acres and in Wirt county 102.5 acres. The average size of farm included in the survey was some-

TABLE 13-Distribution of farms according to total acreage, showing number of farms in each size class

\begin{tabular}{|c|c|c|c|c|c|c|c|c|c|}
\hline \multirow{2}{*}{ ACREAGE } & \multicolumn{8}{|c|}{ DISTRICTS } & \multirow{2}{*}{ Total } \\
\hline & 1 & 2 & 3 & 4 & 5 & 6 & 7 & 8 & \\
\hline $\begin{array}{c}\text { Less than } \\
50 \text { acres } \\
50 \text { to } 99 \\
100 \text { to } 149 \\
150 \text { to } 199 \\
200 \text { to } 249 \\
250 \text { to } 299 \\
300 \text { to } 349 \\
350 \text { to } 399 \\
400 \text { to } 449 \\
450 \text { to } 499 \\
500 \text { or more } \\
\text { Total }\end{array}$ & $\begin{array}{r}20 \\
38 \\
30 \\
11 \\
5 \\
2 \\
1 \\
0 \\
1 \\
1 \\
1 \\
110\end{array}$ & $\begin{array}{r}11 \\
47 \\
38 \\
19 \\
9 \\
4 \\
5 \\
0 \\
0 \\
0 \\
1 \\
134\end{array}$ & $\begin{array}{r}15 \\
46 \\
17 \\
13 \\
7 \\
4 \\
3 \\
0 \\
2 \\
0 \\
1 \\
108\end{array}$ & $\begin{array}{r}21 \\
38 \\
17 \\
17 \\
6 \\
5 \\
3 \\
1 \\
0 \\
1 \\
1 \\
110\end{array}$ & $\begin{array}{r}8 \\
30 \\
23 \\
11 \\
3 \\
5 \\
2 \\
5 \\
1 \\
1 \\
6 \\
95\end{array}$ & $\begin{array}{r}16 \\
22 \\
16 \\
6 \\
4 \\
1 \\
6 \\
1 \\
0 \\
0 \\
1 \\
73\end{array}$ & $\begin{array}{r}14 \\
13 \\
21 \\
5 \\
2 \\
2 \\
4 \\
1 \\
0 \\
1 \\
2 \\
65\end{array}$ & $\begin{array}{r}8 \\
23 \\
16 \\
14 \\
6 \\
5 \\
1 \\
0 \\
1 \\
0 \\
3 \\
77\end{array}$ & $\begin{array}{r}114 \\
257 \\
178 \\
96 \\
42 \\
28 \\
25 \\
8 \\
5 \\
4 \\
15 \\
772\end{array}$ \\
\hline
\end{tabular}



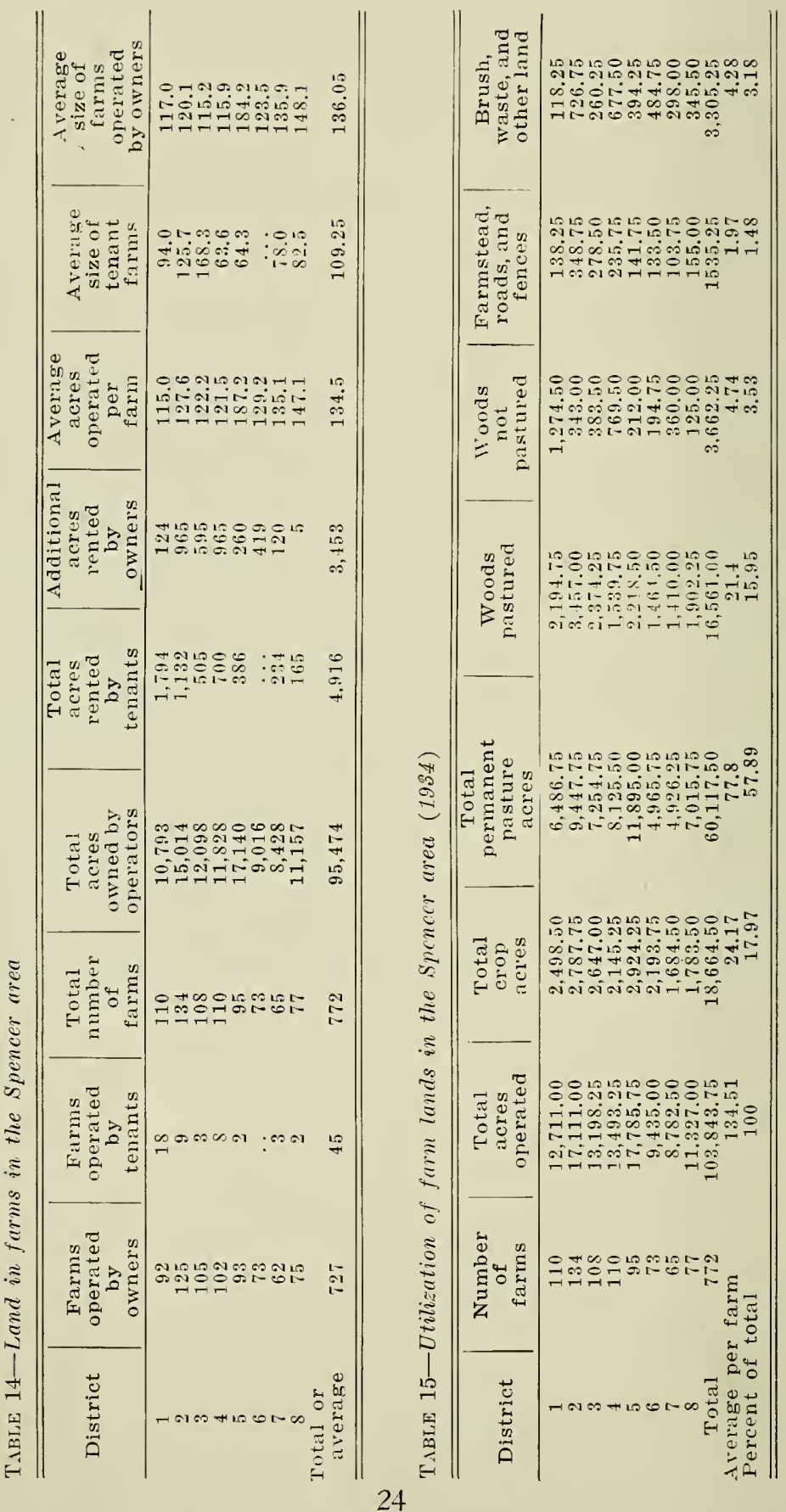

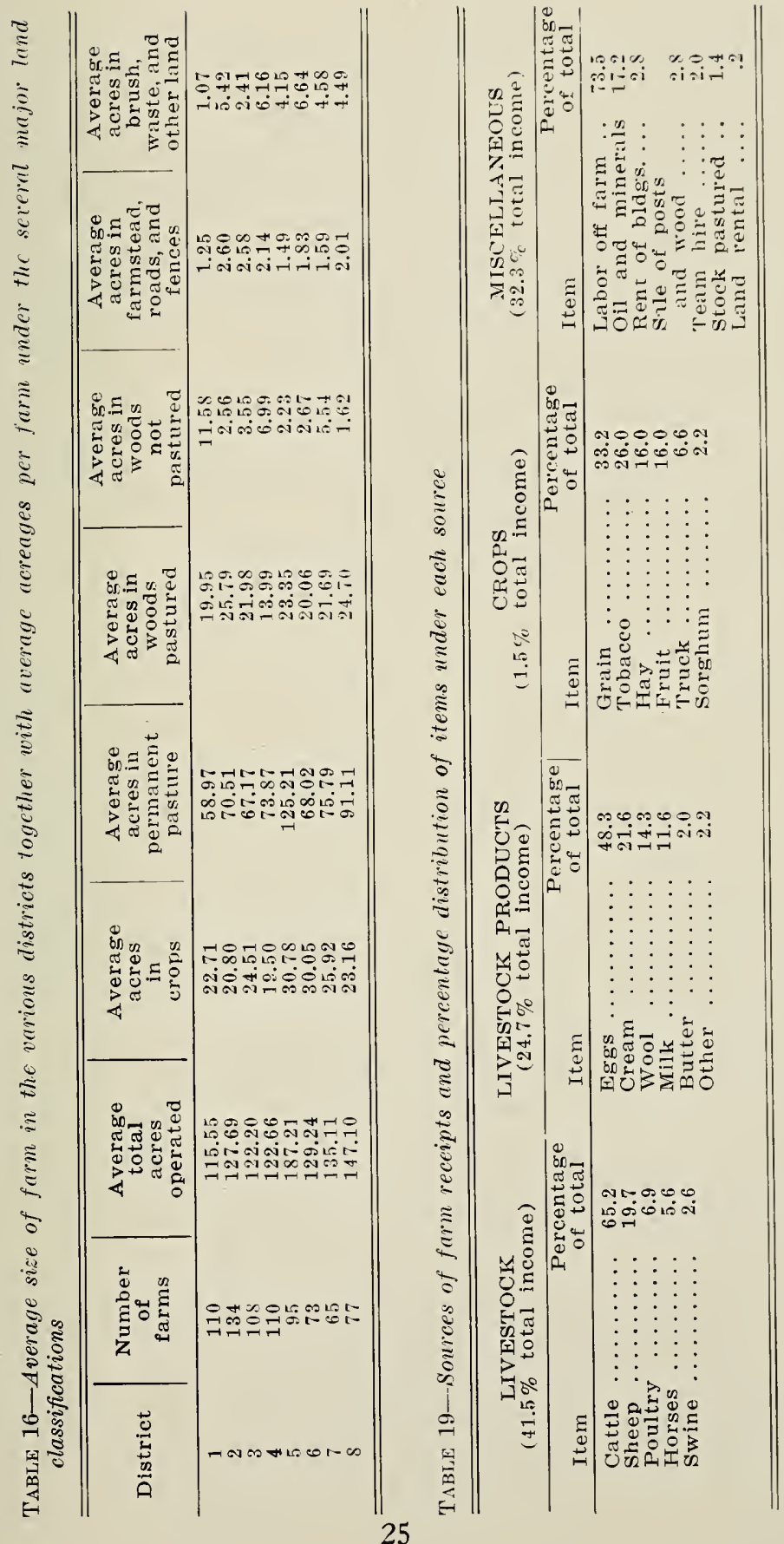
what larger than the average for the two counties as a whole. This may be accounted for partially by the fact that many small part-time farms were not included in the present study.

Land. The farms from which records were obtained included Itilization, a total of $103,8+3$ acres, of which 95,474 acres were operated by owners. Table 14 shows the land in the farms together with the average sizes of tellant and owner-operated farms by districts and for the area.

A comparison of tenant with owner-operated farms on the basis of average size is rather unreliable, because of the small number of tenant farms. In general, however, tenant farms were smaller than the average size of those operated by owners.

The uses being made of these farm lands at the time of the survey were as shown in Tables 15 and 16 . Eighteen percent of the land in farms was in crops, 57.9 percent in pasture, and 19.48 percent in woods; the remainder was in farmsteads, roads, fences, brush, waste. and other lands.

The average size of farms in District 5 is large because it is in this part of the project area that many of the largest farms are situated.

Utilization of Crop Land and Yields per Acre

The crops grown on the farms in the Spencer Area are marketed largely through livestock, as will be shown later. Much crop production is on steep land. This makes production difficult and laborious since hand methods have to be employed extensively. It also intensifies soil conservation problems.

By actual survey only 4.97 percent of the total farm land in the area has a slope of 0 to 4 percent. On 5.88 percent of the land the slope is between 4 and 12 percent and on 17.98 percent the slope is between 12 and 25 percent. The land having a slope between 25 and 40 percent represents 40.68 percent of the total, and 30.49 percent of the land has a slope greater than 40 percent.*

From the foregoing figures it can be seen that for crop production the area of level bottom land is limited. Much of the land now in crops is entirely too steep for successful or sustained crop production.

Much of the bottom land is in permanent meadow. This practice may be due to the fact that the streams periodically flood these narrow bottoms and farmers feel that it is less hazardous to keep them in permanent sod.

Table 17 shows the average acreages of the various crops per farm, the percent each is of the total average crop area per farm, and the average yields per acre of the crops.

Hay and corn are the chief crops grown in the area. This would be expected in a region such as this, devoted almost entirely to livestock enterprises.

* Figures compiled by the soils department of the spencer soil-Conservation Project Staff. 

acres of woods pastured as compared with 3662 acres in woods not pastured. Although it is desirable in proper management of the farm woodlot and from the standpoint of soil conservation to fence the livestock ont of the woods, it had not been done in this area.

Each farmer was asked to estimate the amount of available saw timber on his farm. The total of these estimates for the farms suryeyed was 11,760,400 board feet, or an average of 15,230 board feet per farm. These figures indicate that with proper management the woodlots could be made a worth-while source of income for many farmers.

TABLE 17-Average acreage in various crops per farm, percentage each crop is of total average crop acreage, and average yicld per aere on ning farms in the spencer area (1034)

\begin{tabular}{|c|c|c|c|}
\hline Crop & $\begin{array}{l}\text { Average } \\
\text { acres per } \\
\text { farm }\end{array}$ & $\begin{array}{c}\text { Percentage } \\
\text { of total } \\
\text { crop acres }\end{array}$ & $\begin{array}{l}\text { Average } \\
\text { yields per } \\
\text { acre }\end{array}$ \\
\hline \multicolumn{4}{|l|}{ bity } \\
\hline Clover and timothy .... & 14.23 & 57.17 & 0.8 Tons \\
\hline Alfalfa $\ldots \ldots \ldots \ldots \ldots$ & .003 & .16 & 1.6 Tons \\
\hline 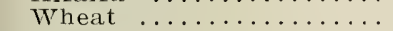 & .32 & 1.31 & 1.1 Tons \\
\hline oat $\ldots \ldots \ldots \ldots \ldots \ldots$ & .66 & 2.69 & 0.6 Tons \\
\hline Soybean .......... & .56 & 2.26 & 1.4 Tons \\
\hline Total hay $\ldots \ldots \ldots \ldots \ldots$ & 15.77 & 63.59 & \\
\hline Corn $\ldots \ldots \ldots \ldots \ldots \ldots \ldots$ & 5.71 & 22.93 & $42.3 \mathrm{bu}$ (ears) \\
\hline Wheat (grain) ........ & 1.09 & 4.41 & 8.3 bu. \\
\hline 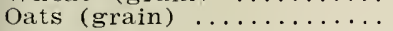 & .01 & .46 & $10.3 \mathrm{bu}$. \\
\hline Fruit $\ldots \ldots \ldots \ldots \ldots \ldots$ & .95 & 4.38 & . \\
\hline Garden $\ldots \ldots \ldots \ldots$ & .66 & 2.68 & $\therefore$ \\
\hline Truck crops .......... & .20 & .84 & $\ldots$ \\
\hline Other $\ldots \ldots \ldots \ldots \ldots \ldots \ldots$ & .18 & .71 & $\ldots$ \\
\hline$\ldots \ldots \ldots$ & $24.57 \%$ & 100.00 & $\cdots$ \\
\hline
\end{tabular}

*The difference between the total 24.57 acres of crops per farm and 24.17, the average acreage devoted to crop production per farm (see Table 15) is explained by the fact that some of the acres were double-cropped.

Livestock The livestock enterprises from which the major part of the income of farms in the Spencer area was clerived were beef cattle, dairy cattle, sheep, and poultry.

The cattle population of the farms in the study here reported was as follows on June 1, 1934:

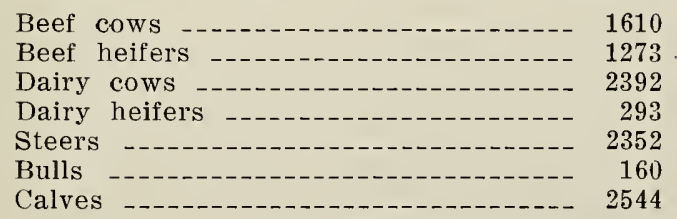

Table 18 shows the kind of livestock on the farms, the average number per farm, the average value of each class per farm on June 1,1934 , and the percentage of the total average value of all livestock represented by each class. 
Hogs on the farms in Roane and 1 irt connties are kept almost exclusively for home consumption. Pork constitutes an important part of the diet for a large grotip of the population.

Horses and mules provided practically all the power for field operations in the area. Only six tractors were found on the 772 farms studied. Many of the horses on farms were old and were not efficient power units. (Forty-eight horses had died on these farms during the year of the record.) There were 990 horses and 116 mules on the farms. The total number of colts reported by all farms was 89 .

There were 54.363 chickens or an average of 73.4 per farm, and a total of 2309 turkeys on the farms studied. Practically all farms had some chickens and on a few of the farms poultry was a major enterprise.

There was an average of 3.1 dairy cows per farm. Most of the farms produced their own supply of dairy products and an appreciable percentage of the receipts from livestock products on these farms came from the sale of dairy products.

TABLE 1S- Kind, number, and value of livestock on farms, June 1, 1934

\begin{tabular}{l|c|c|c}
\hline \hline \multicolumn{1}{c|}{ Kind } & $\begin{array}{c}\text { Average } \\
\text { number } \\
\text { per farm }\end{array}$ & $\begin{array}{c}\text { Average } \\
\text { value } \\
\text { per farm }\end{array}$ & $\begin{array}{c}\text { Percentage of } \\
\text { total average } \\
\text { value }\end{array}$ \\
\hline Cattle $\ldots \ldots \ldots \ldots \ldots \ldots$ & 13.5 & $\$ 274.12$ & 59.1 \\
Horses and mules $\ldots \ldots$ & 1.5 & 94.84 & 20.5 \\
Sheep $\ldots \ldots \ldots \ldots \ldots \ldots \ldots$ & 18.1 & 53.91 & 11.7 \\
Poultry $\ldots \ldots \ldots \ldots \ldots \ldots$ & 2.6 & 2.53 & 5.3 \\
Hogs $\ldots \ldots \ldots \ldots \ldots \ldots$ & 16.19 & 2.4 \\
\hline \hline
\end{tabular}

\section{SOURCES OF FARM RECEIPTS}

The average total receipts per farm for all farms from which records were obtained were $\$ 387.35$. The sources of these receipts and the average amounts from each source per farm were as follows:

$\begin{array}{lcc}\text { Source of Receipts } & \begin{array}{c}\text { Average Amount } \\ \text { Per Farm }\end{array} \\ \text { Livestock } & \$ 160.86 \\ \text { Livestock products } & 95.76 \\ \text { Crops } & 5.94 \\ \text { Miscellaneous } & \end{array}$

Percent of
Total
41.5
24.7
1.5
32.3

Table 19 shows the main sources of receipts broken down into various items with the percentage of the total average receipts per farm from each source represented by each item. (See page 25.)

Sixty-five percent of receipts from the sales of livestock came from the sale of cattle and 19.7 percent from the sale of sheep. Eggs, cream, wool, and milk were the principal livestock products sold. Receipts from the sale of crops were low, amounting to only $\$ 5.94$ per farm. These figures bear out the statement that practically all the crops in this area were marketed through lirestock. 
Receipts from miscellaneous sotrces represented 32.3 percent of all farm income. The chief items under this classification were receipts from operator's work off the farm and oil and mineral rentals and royalties. If income from this latter item is omitted, average miscellaneous receipts per farm would have been $\$ 103.33$ instead of $\$ 124.79$.

Income from Relief Agencics

In connection with a consideration of receipts from work off the farm a study of the amounts of money received by farmers for work on projects administered by relief agencies reveals a situation having both social and who reported that they had received some income from work on C. W. A. or P. W. A. projects during the year. The total amotint received was $\$ 14,955$ or an average of $\$ 82$ per farm reporting.

Forty-six of the 183 farmers mentioned above had also received money or money-equivalent in food and clothing as direct relief. In addition to these 46 families, 79 others had received help as direct relief. The total amount obtained as direct relief was $\$ 3,239$ or $\$ 26$ per farm reporting.

Thus 262 or 33.93 percent of the farm operators interviewed had obtained some income either as direct relief or from work on relief projects. (No amounts received from direct relief were included in income calculations.) The foregoing figures do not include a few farms where members of the family. other than the farm operator, had secured employment on relief projects.

The fact that 16 percent of the farm families had found it necessary to apply for and obtain direct relief indicates something of the general economic conditions on farms in the area.

\section{LABOR INCOME}

Labor income is the common measure of the profitableness of the farming enterprise. It represents the amount which the farm operator receives for his labor and management in a year's time, in addition to the use of a house in which to live and farm products to use in the home, after paying all business expenses of the farm and deducting a charge for the use of capital.

As used in this study, labor income is the difference between the operator's receipts and expenses with unpaid family labor charged at what it would have cost if hired, and interest on the operator's average investment in the farm business charged at 5 percent.

After deducting all expenses from the farm receipts and subtracting also interest on the capital investment at 5 percent, the farmers in the Spencer area had little to show as returus for their labor. In fact, the average labor income for all farms included in the study was minus $\$ 9.93$. Considerably less than half (314) of the farmers made positive labor incomes. 
Table 20 shows a summary of labor incomes for the area by districts. For the farms making positive labor incomes the average was \$237.81. On farms with negative labor incomes the average was minus \$199.89. Viewing the agricultural enterprise in its entirety, from the figures presented, it cannot be considered a profitable one in this area. An analysis as to why the incomes were higher on some farms than on others may reveal the factors chiefly influencing farm profits and suggest possible helps.

A consideration of the size of farms as related to labor incomes revealed little direct correlation between total acreage and labor returns. Similarly, a study of the correlation of labor income with the total number of animal units per farm showed no definite relationship.

The size of farms, of course, does have a definite bearing on the number of animal units. Table 21 shows the farms distributed according to size and the number of animal units per farm.

Size of farm and total aninal units per farm unquestionably have a bearing on farm profits. There are many other factors however which combine with these in affecting returns from the farming enterprise.

\section{MORTGAGE INDEBTEDNESS}

Information relative to mortgage indebtedness at the time of the survey was obtained from the farmers interviewed. Some were unwilling to reveal the facts concerning this item; the total figure given therefore does not represent the full extent of mortgages on these farms.

There were 196 of the farm owners who reported the extent of the mortgages against their farms, the total for all farms being $\$ 236$,188 or an average indebiedness of $\$ 1205.04$ per farm. These figures represent not the original amount of the nortgages but the amount still due in the fall of $193+$. These farmers therefore had cash obligations of interest and principal io be met from what have been shown to be rather limited average cash receipts.

Eighty-four of the 772 farmers reported also that they owed an average of $\$ 280$ each as a result of money borrowed for operating capital.

\section{AN ANALYTICAL STUDY OF 100 HIGH-INCOME FARMS AND 100 LOW-INCOME FARMS}

A study was made of two groups of 100 farms each. One group was composed of farms with positive labor incomes and the other of farms with negative labor incomes. The purpose of such analysis was to determine the factors which caused some farms to pay better than others in the same region.

In selecting these farms all farms which had received 25 percent or more of their cash income from non-farm sources such as labor off the farm and mineral and oil rentals or royalties, were eliminated. 


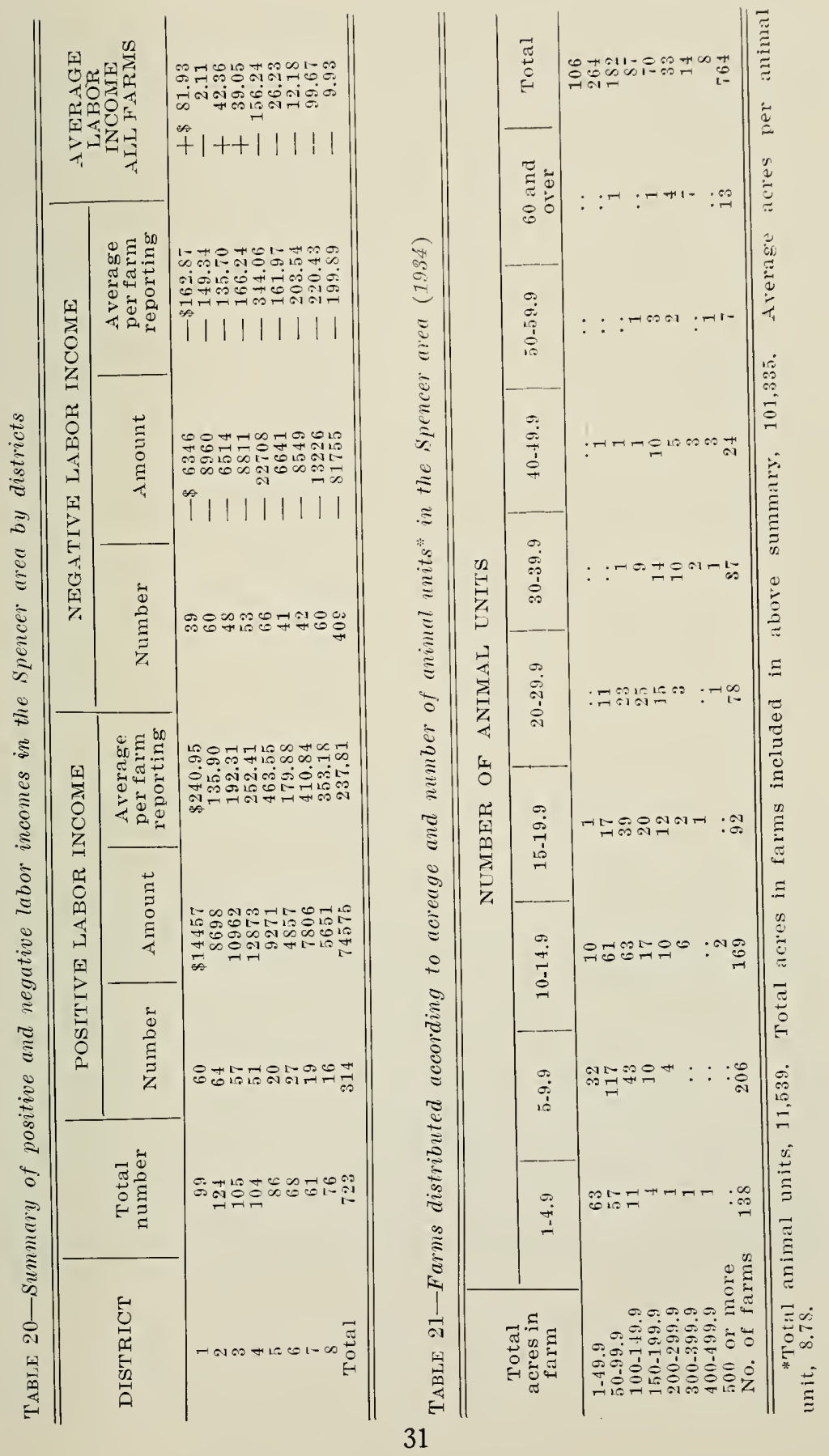


Table 22, presenting a comparison of the two groups of farms as to labor inconle, farm income, receipts, and expenses, shows that gross receipts were $\$ 211.50$ more on the high group than on the low, while expenses were $\$ 152.21$ less.

The relation of size and volume of business to labor income on these two groups of farms is shown in Table 23.

TABLe 22-Labor incomr, farm income, receipts, and expenses

\begin{tabular}{|c|c|c|}
\hline ITFM & $\begin{array}{l}\text { Average } 100 \\
\text { high farms }\end{array}$ & $\begin{array}{l}\text { Average } 100 \\
\text { low farms }\end{array}$ \\
\hline $\begin{array}{l}\text { Labor income } \ldots \ldots \ldots \ldots \ldots \ldots \ldots \ldots \ldots \\
\text { Farm income } \ldots \ldots \ldots \ldots \ldots \ldots \ldots \ldots \ldots \ldots \\
\text { Cash receipts } \ldots \ldots \ldots \ldots \ldots \ldots \ldots \ldots \ldots \\
\text { Cash expenses } \ldots \ldots \ldots \ldots \ldots \ldots \ldots \\
\text { Net change in inventory } \ldots \ldots \ldots \ldots \ldots \ldots \ldots\end{array}$ & $\begin{array}{r}\$ 160.60 \\
315.69 \\
568.90 \\
253.21 \\
111.21 \\
689.11\end{array}$ & $\begin{array}{r}-\$ 254.39 \\
31.32 \\
439.66 \\
405.42 \\
28.95 \\
468.61\end{array}$ \\
\hline
\end{tabular}

TABLE 23-Relation of size and volume of business to labor income

\begin{tabular}{|c|c|c|}
\hline Itrm & $\begin{array}{c}\text { A verage } 100 \\
\text { high farms }\end{array}$ & $\begin{array}{c}\text { Average } 100 \\
\text { low farns }\end{array}$ \\
\hline 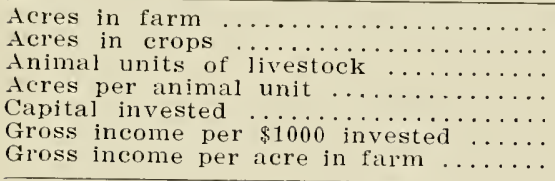 & $\begin{array}{r}142.5 \mathrm{~S} \\
27.31 \\
22.21 \\
6.42 \\
3.555 .62 \\
128.30 \\
3.20\end{array}$ & $\begin{array}{r}195.41 \\
33.20 \\
24.66 \\
7.92 \\
5,692.96 \\
65.76 \\
1.91\end{array}$ \\
\hline
\end{tabular}

The low group of farms was larger in size and had a much higher capital investment than the high group. The low farms had a lower gross income from which to meet higher average expenses, taxes, and interest charges.

The question, "Why, with larger and more valuable farms, were the receipts on low income farms less than on the other group of farms?" immediately presents itself.

The matter of land values is a problem worthy of extended study. Many factors enter into the determination of land values. These are not based on rental values as determined by productivity. Factors such as topography, location, demand, mineral rights, and many others enter into land valuations.

A greater percentage of the area of farms in the high group was in crops. These farms too were stocked more intensively in proportion to size.

Sources of Receipts

Table 24 shows the percentage of receipts from various sources on the two groups of farms. The percentage of receipts from dairy products, sheep and wool, and poultry was greater on the high group of farms. Further analysis of receipts on these farms showed that on the high farms beef cattle receipts were 21 percent greater per animal unit, 109 percent more per 
TABLE 24-Percentage of recoipts from warions sonrecs

\begin{tabular}{|c|c|c|}
\hline Sources of receipts & $\begin{array}{l}100 \text { High- } \\
\text { income farms }\end{array}$ & $\begin{array}{c}100 \text { Low - } \\
\text { income fiorins }\end{array}$ \\
\hline Cattle (beef and dairy) $\ldots \ldots \ldots \ldots$ & 31.8 & 10.6 \\
\hline 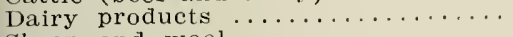 & 12.8 & 10.1 \\
\hline 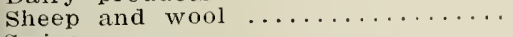 & 19.2 & 17.4 \\
\hline Swine $\ldots \ldots \ldots \ldots \ldots \ldots \ldots \ldots$ & $\therefore 9$ & 1.6 \\
\hline Poultry and poultry products ..... & 24.3 & 18.6 \\
\hline Crops $\ldots \ldots \ldots \ldots \ldots \ldots \ldots \ldots \ldots$ & 2.4 & $\begin{array}{l}2.1 \\
4.5\end{array}$ \\
\hline Horses and mules $\ldots \ldots \ldots \ldots \ldots \ldots$ & 2.4 & $\begin{array}{r}4.6 \\
.6\end{array}$ \\
\hline $\begin{array}{l}\text { Outside labou } \ldots \ldots \ldots \ldots \ldots \ldots \ldots \\
\text { Gas and oil royalties } \ldots \ldots \ldots \ldots \ldots\end{array}$ & .9 & 1.0 \\
\hline $\begin{array}{l}\text { Gas and oil royalties } \ldots \ldots \ldots \ldots \ldots \ldots \\
\text { Other } \ldots \ldots \ldots \ldots \ldots \ldots \ldots \ldots \ldots\end{array}$ & 5.2 & 3.2 \\
\hline
\end{tabular}

dairy cow, 385 percent larger per hen, and 12 percent greater per sheep than on the low farms.

Crop Yields The yields of crops on the high and low income farms are shown in Table 25. Yields of corn, wheat, and oats were considerably greater on the high farms. The yield of alfalfa was larger on the low-income group, but the acreages of this crop were so small as to make this figure of negligible importance. The pasture was apparently somewhat better on the high-income farms. The figures shown in the table were calculated on the basis of all animal units on the farms, and are lower than would be the case if only the animals pastured were considered.

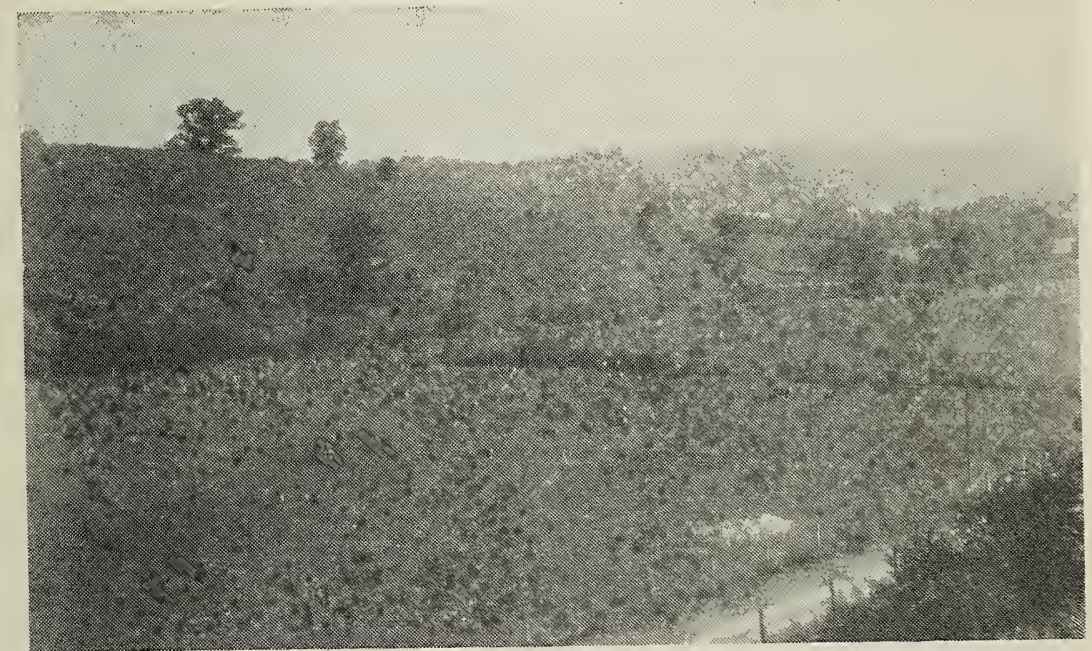

Steers on meadow prior to shipping. An example of the better type of bottom land in the area. This farmer is cooperating with the Soil Conservation Service. The lime shown in foregromnd is a part of this cooperative program 
Soils Twenty-five of the farms in each group were selected as representative, and the soils on each of these farms were studied intensively. A partial answer to differences in crop yields per acre on the two groups of farms may be found in the fact that 17.15 percent of the soils on the selected group of high-income farms were good agricultural soils as compared with 10.25 percent on the lowincome group. The common soil type in the area was Meigs. On these selected groups of high- and low-income farms this soil type constituted 74.95 percent and 78.14 percent of the total soil areas respectively.

TABLE 25-Yields of erops on selected groups of farms

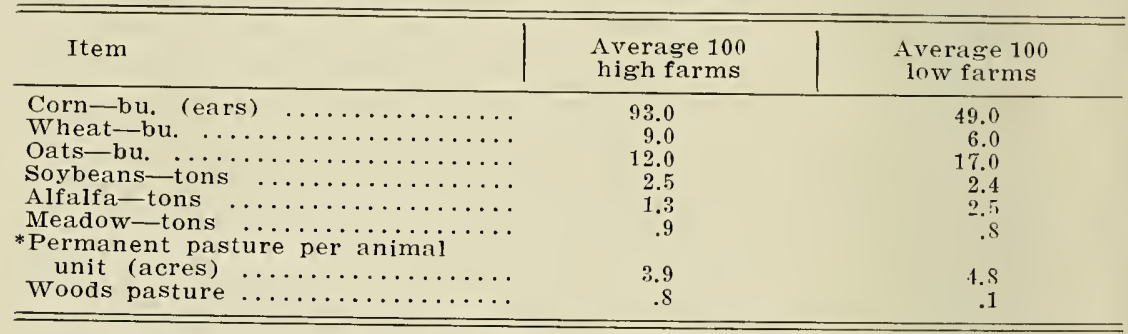

*Calculated on basis of all animal units on farms including cattle, sheep, horses, hogs, and poultry. Animal units calculated on following basis:

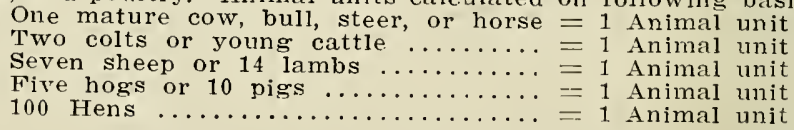

TABLE 26-Erosion conditions on selected groups of farms in the Speneer area and on all cooperating farms

\begin{tabular}{|c|c|c|c|}
\hline Extent of erosion & $\begin{array}{l}\text { Average } \\
\text { of } 25 \\
\text { high } \\
\text { farms }\end{array}$ & $\begin{array}{l}\text { Average } \\
\text { of } 25 \\
\text { low } \\
\text { fains }\end{array}$ & $\begin{array}{l}\text { Average } \\
\text { of all } \\
\text { cooperating } \\
\text { farms in area }\end{array}$ \\
\hline $\begin{array}{l}\text { No erosion } \ldots \ldots \ldots \ldots \ldots \ldots \\
\text { Slight }(0-25 \% \text { top soil lost) } \ldots \ldots \\
\text { Moderate }(25-75 \% \text { top soil lost) } \\
\text { Severe (over } 75 \% \text { top soil lost) }\end{array}$ & $\begin{array}{l}\text { Percent } \\
4.83 \\
8.90 \\
65.66 \\
20.61\end{array}$ & $\begin{array}{l}\text { Percent } \\
4.63 \\
6.85 \\
63.26 \\
25.26\end{array}$ & $\begin{array}{r}\text { Percent } \\
4.69 \\
8.89 \\
62.72 \\
23.70\end{array}$ \\
\hline
\end{tabular}

Erosion A study of the erosion on these selected groups of farms showed little advantage for one group over the other. There was more gullying on the high-income group of farms than on the low group. Table 26 shows erosion conditions as found on these farms. A summary of erosion conditions on all cooperating farms in the area is also included in Table 26 in order to give an indication of the extent of erosion in the area as a whole. The figures show that the productive capacity of the soils in the area has been depleted seriously as a result of erosion. 


\section{SUMMARY}

Ninety-four percent of the farms in the Spencer area were operated by owners.

The average age of the farm operators was 53.4 years.

The average age of the operators at the time of marriage was 25 years.

The number of farms and the total population in Roane and Wirt counties have decreased since 1900 .

There were 647 or 85.2 percent of the farms located on dirt roads; 81 farms or 10.7 percent were along paved roads and 31 or 4.1 percent were on gravel roads.

Of the 647 farms on dirt roads, 116 or 15.3 percent were more than 5 miles from the nearest paved road.

More than one-half of the farms were further than 5 miles from any market.

Churches and schools were well distributed throughout the area and could be reached from the majority of the farms without excessive travel.

Three hundred of the farms were ten miles or more from the nearest high school.

Wells were the chief source of water supply. In a large number of cases the water supply was inadequately protected against surface run-off and seepage.

One hundred sixty of the farm houses were in poor condition and 200 had never been painted.

There were 441 of the farm operators (or 61.9\%) who had attended school eight years or less, and 455 or 75.2 percent of the wives who had received no more than a common-school education.

The average number of children per farm family was 4.1. An average of 5.58 persons lived in the operator's household at the time of the survey.

There were 814 sons and 713 daughters of the farm operators who had reached 21 years of age or were married. Of these, 41 percent of the boys and 47 percent of the girls had left the area.

Only 20 of the 772 farm operators had not been born and reared on a farm.

The average size of farm in the area was 134.5 acres.

The average capital investment per farm was $\$ 3713$, of which the investment in real estate represented nearly 85 percent.

Eighteen percent of the total land area in farms was in crops, 57.9 percent in pasture, and 19.5 percent in woods.

Only 10.85 percent of the land area had a slope of less than 12 percent while on 30.49 percent of the area the slope was greater than 40 percent. Much crop production was on steep slopes necessitating considerable hand labor in planting, cultivating, and harvesting.

Little commercial fertilizer was used in the area during the year covered by the records. 
Average crop yields were low.

The area is primarily a livestock region, 41.5 percent of all farm receipts coming from sales of livestock and 24.7 percent from the sale of livestock products.

Sixteen percent of the farm families included in the study had obtained direct relief either as food products, clothing, or in cash to the average amonint of $\$ 26$ per farm.

The average total rereipts per farm were \$387.35, of which 32 percent came from non-agricultural sources.

The average labor income per farm was minus $\$ 9.93$.

Only 314 of the farms made positive labor incomes.

There were 196 farm owners who reported mortgages against their farms, the average indebtedness being $\$ 1205$ per farm. This does not represent the full mortgage indebtedness for all farms in the study since some farmers were unwilling to give information on this item.

With present incomes it is going to be difficult for a large number of these farmers to meet mortgage obligations and at the sane time provide adequately for their families.

Some portions of the area have little prospect of ever yielding much more than subsistence from an agricultural standpoint.

Incomes on the high-income farms were greater, largely because of better soils; more intensive farming (higher crop yields, better feeding methods, higher returns per acre and per animal unit, etc.); lower interest costs due to smaller average capital investment; and lower taxes.

Methods that must be emploved in much of the area and the returns obtained from farming are not particularly alluring to the younger generation; approximately one-third of the sons who had left home were engaged in farming and about the same percentage of the daughters had married farmers.

Much land now in crops is too steep for cultivation.

The facts and figures cited point to the necessity of the adoption of a more intensive and judicious land-use program.

Farmers in the Spencer area are not now obtaining sufficient income to maintain and conserve soil fertility and enjoy with their families a desirable standard of living. 
